1

\title{
TEMPERATURE, SALINITY AND OXYGEN CLIMATOLOGY OF AFRICAN CONTINENTAL SHELF WATER, SOUTH OF THE EQUATOR, AND CHANGES SINCE 1945
}

\section{Stephanie de Villiers}

AEON-ESSRI (Africa Earth Observatory Network-Earth Stewardship Science Research Institute), Nelson Mandela University, Port Elizabeth, South Africa.

\section{ABSTRACT}

The first temperature, salinity and oxygen climatologies for waters of the continuous southern African continental shelf is presented. It is based on oceanographic data collected since 1945, sub-sampled at depths of 5,50 and $100 \mathrm{~m}$ on a mixed-spatial grid with $0.25^{\circ}$ to $0.5^{\circ}$ resolution. The climatologies capture spatial heterogeneities and seasonal variability in key ocean variables for the southern African shelf in unique detail. The results correspond relatively well with biogeographic boundaries informed by classification schemes grounded in taxonomy, but questions the value of the Large Marine Ecosystem approach. Analysis of decadal trends demonstrates the inherent complexity and spatial heterogeneity associated with environmental variability, and suggest the possibility that decadal periodicities are in the process of being disrupted by a longer-term trend. The overall pattern is that southern African West and South coast shelf waters are becoming warmer, except for some upwelling areas, where cooling is evident. Benguela and Agulhas Bank shelf water are also becoming more oxygen depleted. 


\section{INTRODUCTION}

Continental shelves account for only about $8 \%$ of the world's marine areas, but are host to more marine biodiversity, productivity and human activities than offshore waters, and provide ecosystem services comparable in magnitude to that of all terrestrial habitats (UNEP, 2006; Costanza et al., 1997). The African continental shelf is host to natural resources of particular and critical socio-economic value for coastal communities (Kainge et al., 2020). Understanding the significance of observed changes in ocean variables such as temperature and wind (Roualt et al., 2010; Leduc et al., 2010; Santos et al., 2012; Beal et al., 2016; Vizy et al., 2018; Malan et al., 2019), and ecosystem changes such as species range shifts and variability in species abundance (Cockcroft et al., 2008; Roy et al., 2007; Coetzee et al., 2008; Yemane et al., 2014; Blamey et al., 2015; Jarre et al., 2015a; Van der Linge et al., 2016; Kainge et al., 2017; Van der Linge and Hampton, 2018), have transdisciplinary significance (Potts et al., 2014; Augustyn et al., 2017; Hobday and Pecl, 2014; Kainge et al., 2020). Construction of climatological maps of key ocean variables, based on the calculation of mean fields from historical data sets, are valuable reference tools in this regard.

Only a limited number of climatologies have been constructed specifically for shelf areas, e.g. for the eastern seaboard of North America (Atkinson et al., 1983; Blanton et al., 2003; Bisagni, 2016; Richaud et al., 2016) and the Ross Sea off Antarctica (Russo et al., 2011). Most climatologies of key ocean variables exclude data from "land grid-boxes", i.e. coastal areas and portions of the inner continental shelf (Levitus, 1982; Levitus and Boyer, 1994; Ridgway et al. 2002; Boyer et al. 2005; Boyer et al. 2018). Large parts of the African shelf is relatively data poor (Boyer et al., 2018), and irregular and infrequent sampling presents unique challenges to the production of regional scale climatological maps. This study presents the first such climatological maps for waters of the southern African continental shelf, from the equator off the west coast of Gabon, to the equator and the east coast of Somalia.

Our knowledge of the morphology of the African continental shelf is much less advanced than for most other continents (Chiocci and Chivas, 2014). The shelves of the West, South and East African continental margins comprise passive continental margins characterised by thick sediment accumulations where fluvial supply is high, such as off the mouths of the Congo, Orange, Tugela, Limpopo, Save and Zambezi rivers (Scrutton, 1982). The coastline is dominated by lowland coasts with long unbroken sandy beaches (Orme, 1982); rugged mountainous coasts are rare, except along the most southern margin. The southern Africa continental shelf varies considerably in width, as defined by the offshore distance of the $200 \mathrm{~m}$ depth isobath (Fig 1A). In the south, the Agulhas Bank has a maximum offshore extent of about $270 \mathrm{~km}$ (Dingle et al., 1978). The shelf areas off Namibia and South Africa's west coast are also notably wider, compared to those off Angola (Bremner, 1981) and most of the East Coast (Schumann, 1998). The shelf regions off eastern South Africa and off northern Mozambique are particularly narrow, often less than $10 \mathrm{~km}$ wide, with steep offshore slopes (Schumann, 1998).

The southern Africa shelf is influenced by four surface ocean current systems, the Angola, Benguela, Agulhas and East African Coastal currents (Fig 1A). The warm southward flowing Angola Current derives primarily from the South Equatorial Under Current (SEUC) and the Guinea-Congo 
1 boundary of the Angola Gyre, which is a large scale current field centered near $17^{\circ} \mathrm{S}, 5^{\circ} \mathrm{E}$ (Gordon and Bosley, 1991). Embedded in the gyre is the Angola Dome, centered at $10^{\circ} \mathrm{S}, 9^{\circ} \mathrm{E}$ (Mazeika, 1967). The Angola Current splits into two at the southern boundary of the Angola Gyre at $\sim 16$ to $17^{\circ} \mathrm{S}$ : a westward continuation, which closes the Angola gyre, and the Benguela Poleward Under Current (BPUC), which flows along the upper slope as far south as $27^{\circ} \mathrm{S}$ off Namibia (Mercier et al, 2003; Tchipalanga et al., 2018). At the confluence of the Angola Current and the cold northward flowing Benguela Current is a sharp thermal front, the Angola-Benguela Front (ABF, Fig 1A). The ABF migrates in an eastward and southward direction in response to the late austral summer (Feb - April) relaxation of equatorial easterly winds (Dias, 1983; Stramma and Schott, 1999; Ekau and Verheye, 2005). The cool Benguela Current flows northward off the west coast of South Africa and Namibia (Fig 1A), from approximately $35^{\circ} \mathrm{S}$ to just south of the ABF. It is driven by the prevailing South Easterly trade winds of the South Atlantic Ocean. Inshore of the Benguela Current, the south easterly winds cause inner shelf upwelling of cold nutrient-rich water (Olivar and Shelton, 1993; Shannon, 1995).
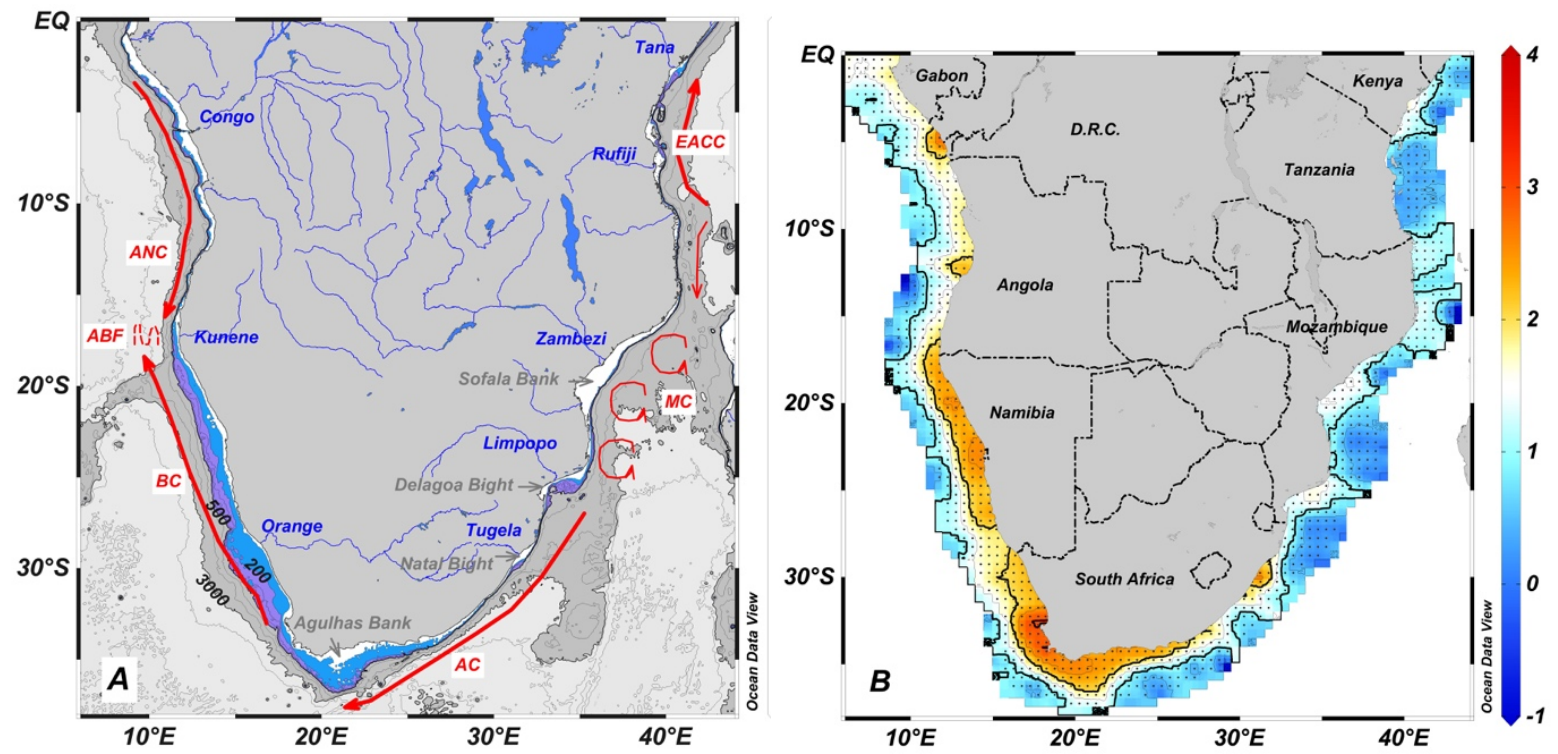

Fig 1. A: Bathymetric map of the study area; the coast to $100 \mathrm{~m}$ depth interval is filled in with white, 100 to $200 \mathrm{~m}$ blue, 200 to $500 \mathrm{~m}$ purple (thin solid lines indicate 300 and $400 \mathrm{~m}$ depth intervals); 500 to $3000 \mathrm{~m}$ dark grey (thin solid lines indicate depths at $500 \mathrm{~m}$ intervals), depths below $3000 \mathrm{~m}$ are light grey (with thin solid lines indicating $500 \mathrm{~m}$ depth intervals). Also shown are the major continental river systems. B: Total number of sampling stations for which oceanographic data is publicly available (as WOD and SADCO datasets) for 1900 to 2020 , plotted as $\log$ (\#stations) per $0.5^{\circ}$ latitude $\times 0.5^{\circ}$ longitude bin. The black dots indicate the center points of the $0.5^{\circ} \times 0.5^{\circ}$ degree bins used in this study.

The warm Agulhas Current dominates the shelf areas off the south and east coasts of South Africa (Fig 1A). The current originates near $\sim 28^{\circ} \mathrm{S}$ off Mozambique and transports warm water in a southwesterly direction towards its retroflection area off the tip of Africa (Lutjeharms and van Ballegooyen, 1988; Lutjeharms and Cooper, 1996). The Agulhas and Benguela currents play a significant role in global ocean heat transfer between the Southern and the Northern Hemisphere (Duncombe Rae, 1991). The ocean area between $\sim 10^{\circ} \mathrm{S}$ and $28^{\circ} \mathrm{S}$ along the east African coast is occupied by the Mozambique Current, a discontinuous current characterised by southward drifting anti-cyclonic eddies (Lutjeharms et al., 2012). The East African Coastal Current, or Zanzibar Current, flows northward from 
$\sim 10^{\circ} \mathrm{S}$ along the east African coast (Swallow et al., 1991). There is close interaction in many cases

2 between shelf and slope morphology and current movement, as has been described for south-eastern

3 Africa (Lutjeharms 2006).

Several biogeographic divisions have been proposed for the southern Africa continental shelf and offshore ocean areas. The large marine ecosystem (LME) approach is widely used by regional scientists and resource managers (Sherman, 1993), despite its "amorphous" nature (Pauly, 1998). The study area hosts the Benguela Current Large Marine Ecosystem (BCLME), the Agulhas Current LME (ACLME) and the Somali Coastal Current LME (SCCLME) (Fig 2).

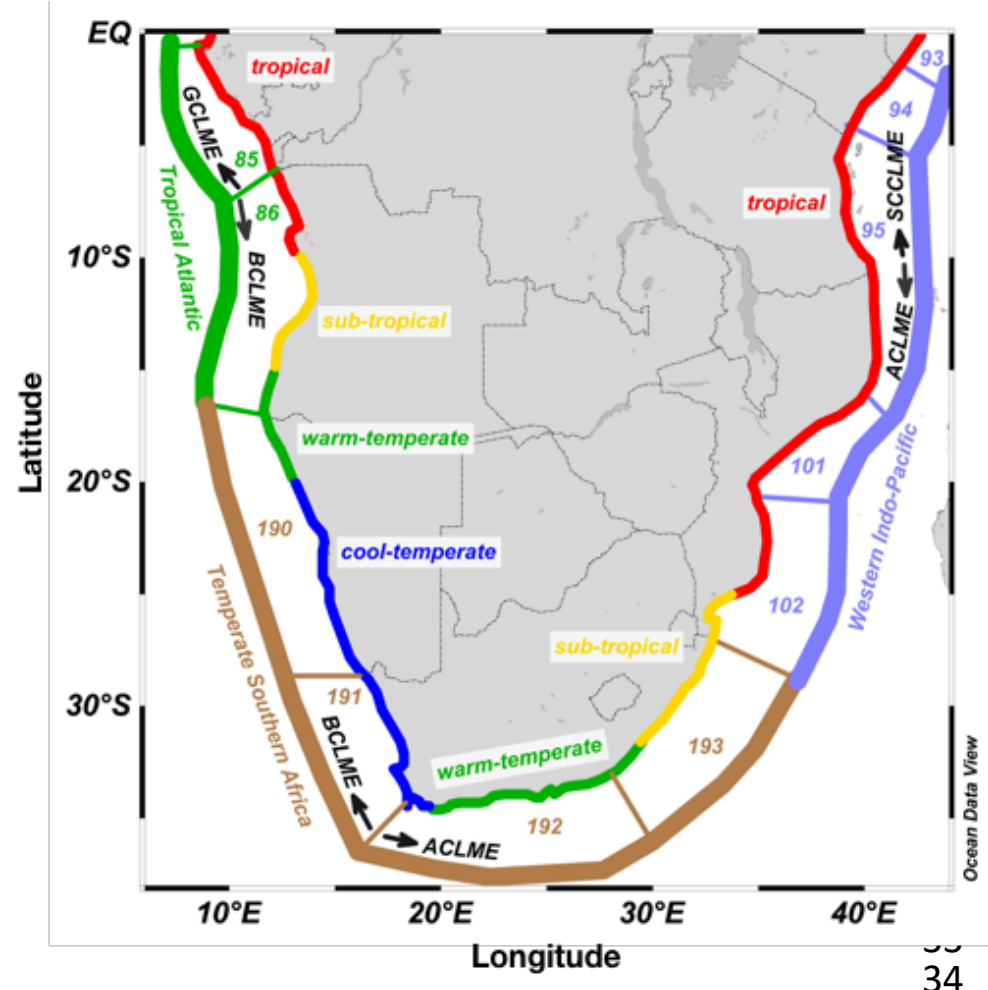

Fig 2. Map of the Tropical Atlantic (thick green line), Temperate Southern Africa (thick brown line) and Western Indo-Pacific (thick purple line) biogeographic Realms of Spalding et al. (2007), subdivided into these Provinces (and numbered ecoregion blocks): Gulf of Guinea (85 - Gulf of Guinea South, 86 - Angolan), Benguela (190 - Namib, 191 - Namaqua), Agulhas (192 - Agulhas Bank, 193 Natal), Western Indian Ocean (102 - Delagoa, 101 - Bight of Sofala/Swamp Coast, 95 - East African Coral Coast, 94 - Northern Monsoon Current Coast), Somali/Arabian (93 - Central Somali Coast). Large marine ecosystems are indicated in black (LME's; Sherman, 1993): GCLME Guinea Current LME, BCLME Benguela Current LME, ACLME Agulhas Current LME, SCCLME Somali Coastal Current LME. Thin colored lines along the coastline indicate the biogeographical zones defined by Briggs and Bowen (2012) and Whitfield (2005), as modified by Potts et al. (2015).

The BCLME is one of the most productive ocean ecosystems in the world in terms of biomass production and fishery resources (Spalding et al., 2012). The relatively narrow Northern Benguela shelf, off Angola, is characterized by spatially extensive upwelling. The wide Central Benguela (off Namibia) and South Benguela (off South Africa) shelf areas, in contrast, host several discrete upwelling cells (Shannon, 1995). The hierarchical biogeographic classification system of Spalding et al. (2007) was developed specifically and uniquely for the benthic and pelagic biotas of coastal and shelf areas. This nested system describes three Realms, five Provinces and eleven biogeographic Ecoregions for the southern Africa continental shelf (Fig 2). Other classification systems that rely primarily on taxonomy (Briggs and Bowen, 2012; Potts et al. 2015) propose up to 7 biogeographic zones for the African shelf and coastline south of the equator (Fig 2).

Temperature has been proposed to be the key environmental variable correlating with the distribution of species and range shifts in shelf areas, as is the case for the open ocean (Spalding et al., 2007; Potts et al., 2015; Sunday et al., 2012; Cheung et al., 2013; Morley et al., 2018). It is also 
increasingly recognized that temperature extremes rather than average values determine population survival at the warm edge of a species' temperature range (Pinsky et al., 2019). Additionally, abrupt ecosystem change can be caused by extreme climatic events such as marine heatwaves, that is prolonged periods of anomalously warm seawater (Shannon et al., 1986; Gammelsrød et al., 1998; Mills et al., 2012; Cavole et al., 2016; Wernberg et al., 2016; Rouault et al., 2017; Jones et al., 2019; Smale et al., 2019). Globally, marine heatwaves have increased in frequency and duration since the early 20th century (Oliver et al., 2018), and global models project this trend to continue through the 21st century (Oliver et al., 2019). Temperature and dynamic temperature ranges, however, cannot be considered is isolation of other variables that influence marine species distribution, dissolved oxygen is also particularly important (Jarre et al., 2015b; Hamukuaya et al., 1998; Mbatha et al., 2019; Woodhead et al., 1997). This study presents annual and seasonal climatologies for temperature, salinity and oxygen for the continuous southern African continental shelf at depths of 5,50 and $100 \mathrm{~m}$. Interdecadal changes are also evaluated and discussed in the context of documented complex ecosystem changes that have been observed in the study area.

\section{DATA AND METHODS}

\subsection{Study area, data sources and distribution}

For the purpose of this study, data was extracted for the area 0 to $40^{\circ} \mathrm{S}, 5$ to $45^{\circ} \mathrm{E}$, from two open access online sources: WOD18 (World Ocean Database 2018, available at ncei.noaa.gov; Boyer et al., 2018) and SADCO (Southern African Data Centre for Oceanography, presently hosted at sadco.ocean.gov.za). The databases contain both high resolution CTD (i.e. Conductivity-TemperatureDepth data at 2 or $5 \mathrm{~m}$ depth intervals) and low resolution bottle (called OSD or Ocean Station Data in the WOD) data sets. WOD OSD data was retrieved at standard (as opposed to observed) depths of 0 , 5,50 and 100. The data sets were combined and stations with repeated timestamps removed. The consolidated WOD-SADCO data set comprises 77259 individual stations within the 0 to $40^{\circ} \mathrm{S}, 5$ to $45^{\circ} \mathrm{E}$ area. About $85 \%$ (65 852) of these stations are located within 3 degrees of the African coastline (Appendix 1).

An outlier filter (Richaud et al., 2016) was applied to this data set as a quality control measure. For this purpose, all data set values for temperature, salinity and oxygen were grouped into $1^{\circ} \times 1^{\circ}$ bins, and the mean and standard deviation $(\sigma)$ calculated for each variable at the surface ( 0 and 5$), 50$ and $100 \mathrm{~m}$. All values more than 3 times the standard deviation away from the mean were considered outliers and removed, with the exception of surface salinity in bins adjacent to river mouths. Only one iteration of this procedure was carried out, no further data exclusion took place and less than $0.2 \%$ of the total data was removed through this procedure (listed in Appendix 2). The data set was also screened for spatial and temporal clustering (defined as multiple data points within a $24 \mathrm{~h}$ period and 5 $\mathrm{km}$ radius) as a precautionary measure. It is important to note that historical data, in particular biogeochemical data such as oxygen, "have been measured using a variety of manual and automated analytical techniques" (Boyer et al., 2018) and the details of these are often not contained in metadata. Comparison of measurement techniques and uncertainties fall outside the scope of the WOD and also this study.

The spatial and temporal coverage of the data set, excluding the above outliers, was then evaluated by counting the number of OSD and CTD casts in $0.5^{\circ} \times 0.5^{\circ}$ bins (Fig 1B, Appendix 1), for a 3 degree 
distance away from the coastline. This was repeated for each of the variables (Appendix 1). Although the continental shelf is the focus of this study, it seemed sensible to include data from offshore of the $200 \mathrm{~m}$ depth isobath. The $0.5^{\circ} \times 0.5^{\circ}$ bins closest to the coast, i.e. along the inner shelf, were termed $\mathrm{H}_{\text {coast }}$ (or $\mathrm{H}_{0.5^{\circ}}$ ). Successive bins further offshore $\left(\mathrm{H}_{1}{ }^{\circ}, \mathrm{H}_{1.5^{\circ}}, \mathrm{H}_{2}{ }^{\circ}, \mathrm{H}_{2.5^{\circ}}\right.$ and $\mathrm{H}_{3^{\circ}}$ ) were aligned in an eastwest direction for the West (west of $18.5^{\circ} \mathrm{E}$ ) and East (east of $26.5^{\circ} \mathrm{E}$ ) coast areas, and in a south-north

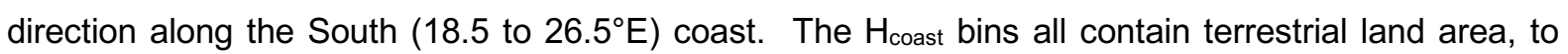
different degrees. The distribution of data with depth (5,50 and $100 \mathrm{~m}$ ), time of day (four 6 hour intervals from 00:00-05:59 to 18:00-23:50) and time (5 year increments from 1945 to 2019) was established per $0.5^{\circ} \times 3^{\circ}$ bin, using temperature cast data (Appendix 1 ). In summary, $100 \%$ of the total casts contained temperature data, with equivalent values of $91 \%$ for salinity, $54 \%$ for oxygen. Additionally, $99 \%$ of the casts contained temperature data at the surface, $49 \%$ at $50 \mathrm{~m}$ and $37 \%$ at $100 \mathrm{~m}$ depth.

\subsection{Analysis of intra-annual variability and seasonality in $\mathrm{H}_{\text {coast }}$ bins}

Average monthly temperature values were calculated at depths of 5,50 and $100 \mathrm{~m}$ for each $\mathrm{H}_{\text {coast }}$ bin, from 0 to $34.5^{\circ} \mathrm{S}$ along the West Coast, 18.5 to $26.5^{\circ} \mathrm{E}$ along the South Coast and 34.5 to $0^{\circ} \mathrm{S}$ along the East Coast (Fig 3). Constructing an annual profile consisting of monthly values (with $n>3$ ) was possible for most of the $\mathrm{H}_{\text {coast }}$ bins, with minimal interpolation required, except for the East Coast and in particular north of $28^{\circ} \mathrm{S}$ along the East Coast (Table 1; Fig 3). In the latter instance, monthly data gaps were filled with the average of four values: that of the preceding and following month of the same

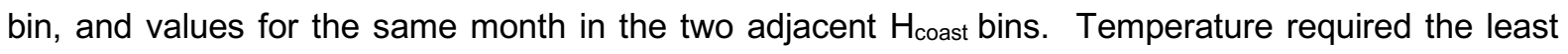
amount of gap-filling, and typically up to a factor of two less than salinity and oxygen. In an offshore direction, i.e. $\mathrm{H}_{\text {coast }}$ towards $\mathrm{H}_{3}$, the amount of gap-filling required for the construction of annual profiles consisting of monthly values is excessive in most areas, even for temperature (Table 1). The method adopted by Ridgway et al. (2002) and Richaud et al. (2016), that is of assuming an annual profile and then using it to calculate monthly values for gap-filling purposes, and calculating an annual climatological average from that, was therefore not adopted in this study. This study, rather, constructed an annual climatology from four seasonal values. The choice of months to be grouped together to constitute a season, was based on the intra-annual variability observed in the $H_{\text {coast }}$ bins, as detailed below.

Intra-annual surface temperature variability in $\mathrm{H}_{\text {coast }}$ bins indicated that the warmest month of the year, along the entire southern African shelf, is most often February (55\%), followed by March (34\%) and January (11\%) (Fig 3A, 4A). At the surface, the coldest month is most often August ( $46 \%$, blue line in Fig 3A; Fig 4B), followed by July (23\%) and September (20\%). At 50 and $100 \mathrm{~m}$ depths, however, the warmest and coldest monthly values were generally observed at different times of the year than at the surface and the seasonal pattern is more complex and geographically variable than at the surface (Fig 3, 4). February is the warmest month of the annual cycle for $20 \%$ and $0 \%$ of the $\mathrm{H}_{\text {coast }}$ bins at 50 and $100 \mathrm{~m}$, respectively, and August the coldest month for $24 \%$ and $22 \%$ of the $\mathrm{H}_{\text {coast }}$ bins, at these two deeper depths. The geographic complexicity in intra-annual variability were captured in shelf segment composites, consisting of the average of all the $\mathrm{H}_{\text {coast }}$ bin monthly values in that segment; Gabon-Angola or WC: $0-17^{\circ} \mathrm{S}$, Central Benguela or WC: $17-28^{\circ} \mathrm{S}$, Southern Benguela or WC: 28 $34^{\circ} \mathrm{S}$, Agulhas Bank or SC: $18.5-26.5^{\circ} \mathrm{E}$ and the southern East Coast or EC: $25-34^{\circ} \mathrm{S}$ (Fig 5). Based on the results of this evaluation, months were grouped together for the construction of seasonal average 
1 temperature, salinity and oxygen values, as follows: Jan-Feb-Mar (JFM) = summer; Apr-May-Jun (AMJ)

2 = autumn; Jul-Aug-Sep (JAS) = winter; and Oct-Nov-Dec (OND) = spring.

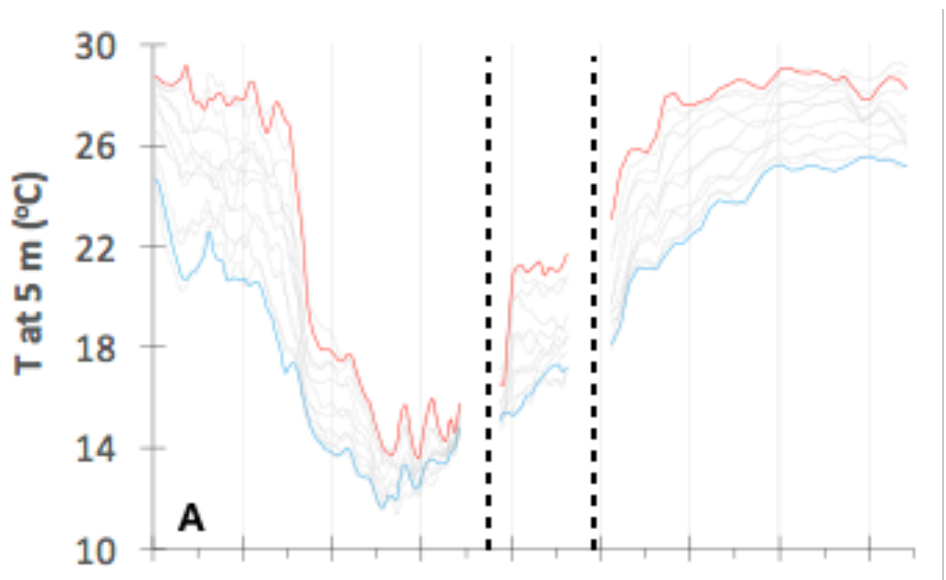

$010 \mathrm{~S} 20 \mathrm{~S} 30 \mathrm{~S} 20 \mathrm{E} 35 \mathrm{~S} 25 \mathrm{~S} 15 \mathrm{~S} 5 \mathrm{~S}$
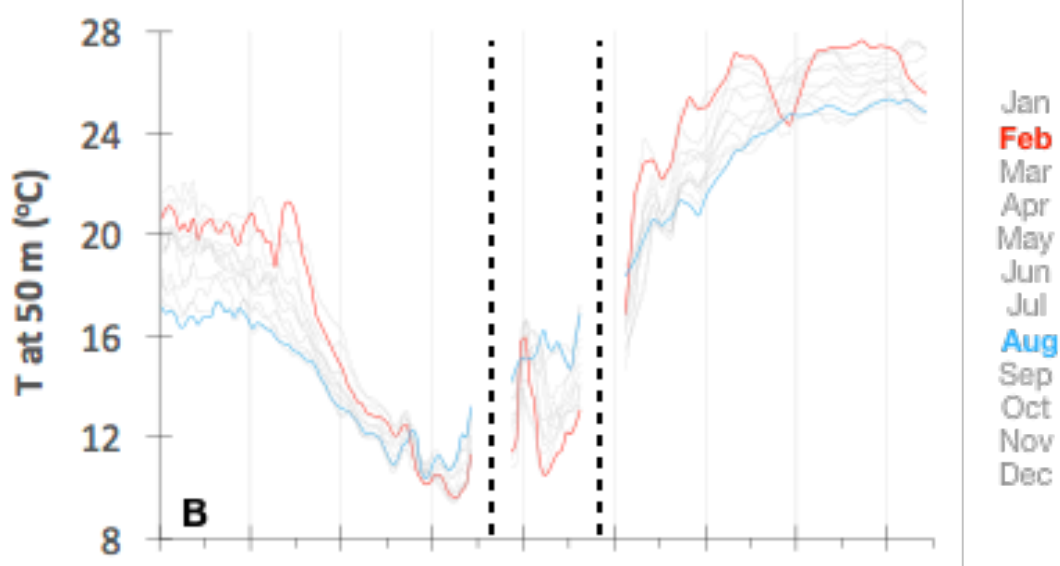

$010 \mathrm{~S} 20 \mathrm{~S} 30 \mathrm{~S} 20 \mathrm{E} 35 \mathrm{~S} 25 \mathrm{~S} 15 \mathrm{~S} 5 \mathrm{~S}$

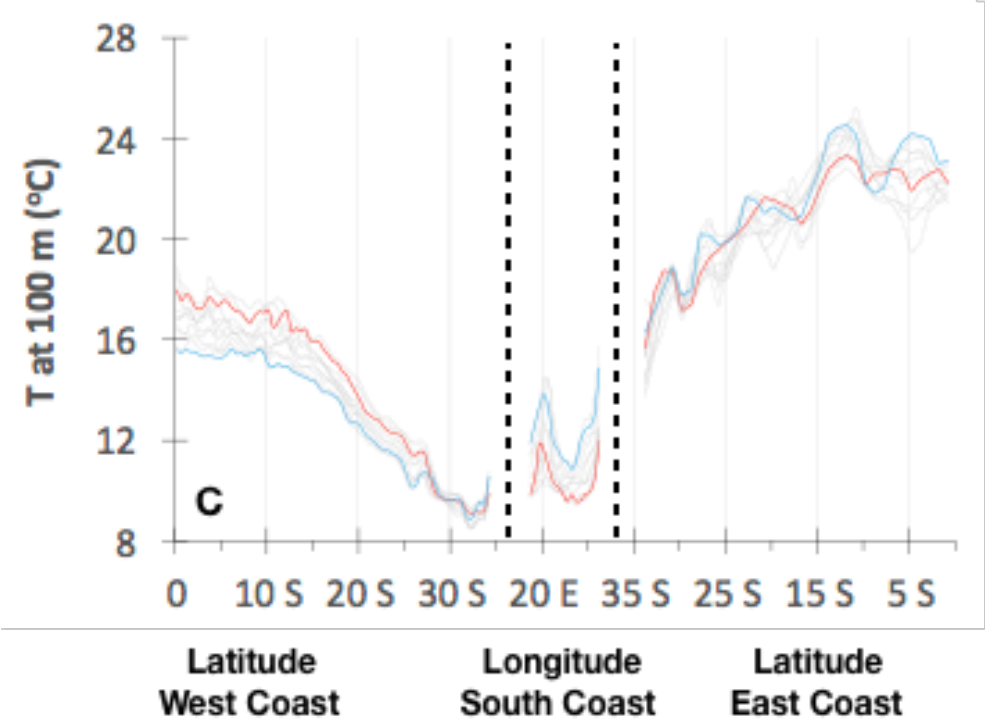

4

Fig 3. Comparative average monthly temperature values at depths of 5,50 and $100 \mathrm{~m}$ (A to $\mathrm{C}$ ) for $\mathrm{H}_{\text {coast }}$ bins, from 0 to $34.5^{\circ} \mathrm{S}$ along the West Coast, 18.5 to $26.5^{\circ} \mathrm{E}$ along the South Coast and 34.5 to $0^{\circ} \mathrm{S}$ along the East Coast. The red lines highlight values for February, most often the warmest month of the year in the study area, and the blue lines highlight values for August, most often the coldest month of the year. Grey lines indicate the other ten months of the year. 


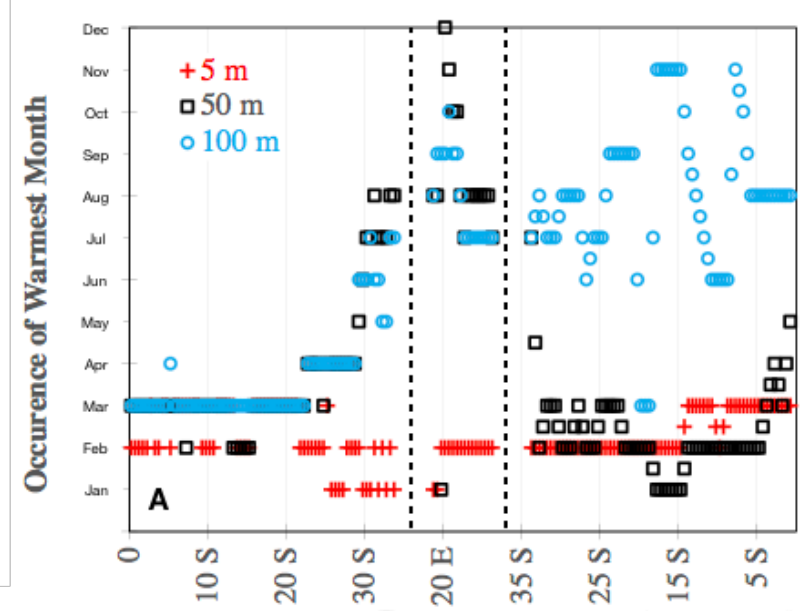

Fig 4. Months in which the highest $(A)$ and lowest $(B)$ monthly average $T$ values are observed in $\mathrm{H}_{\text {coast }}$ bins.

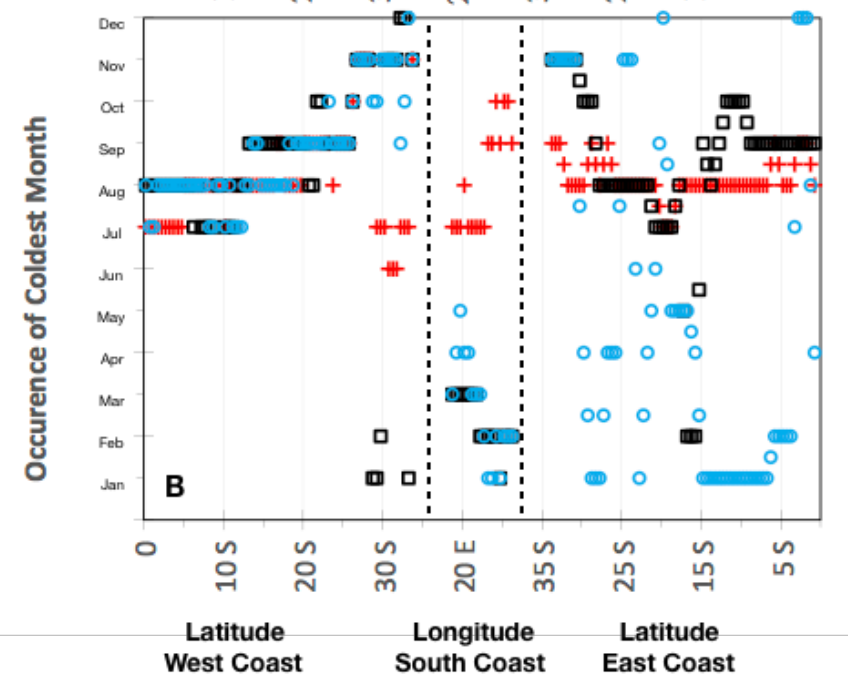

9

$\begin{array}{lllll}\text { WC: } 0-17^{\circ} \mathrm{S} & \text { WC: } 17-28^{\circ} \mathrm{S} & \text { WC: } 28-34^{\circ} \mathrm{S} & \text { SC: } 18.5-26.5^{\circ} \mathrm{E} & \text { EC: } 25-34^{\circ} \mathrm{S}\end{array}$
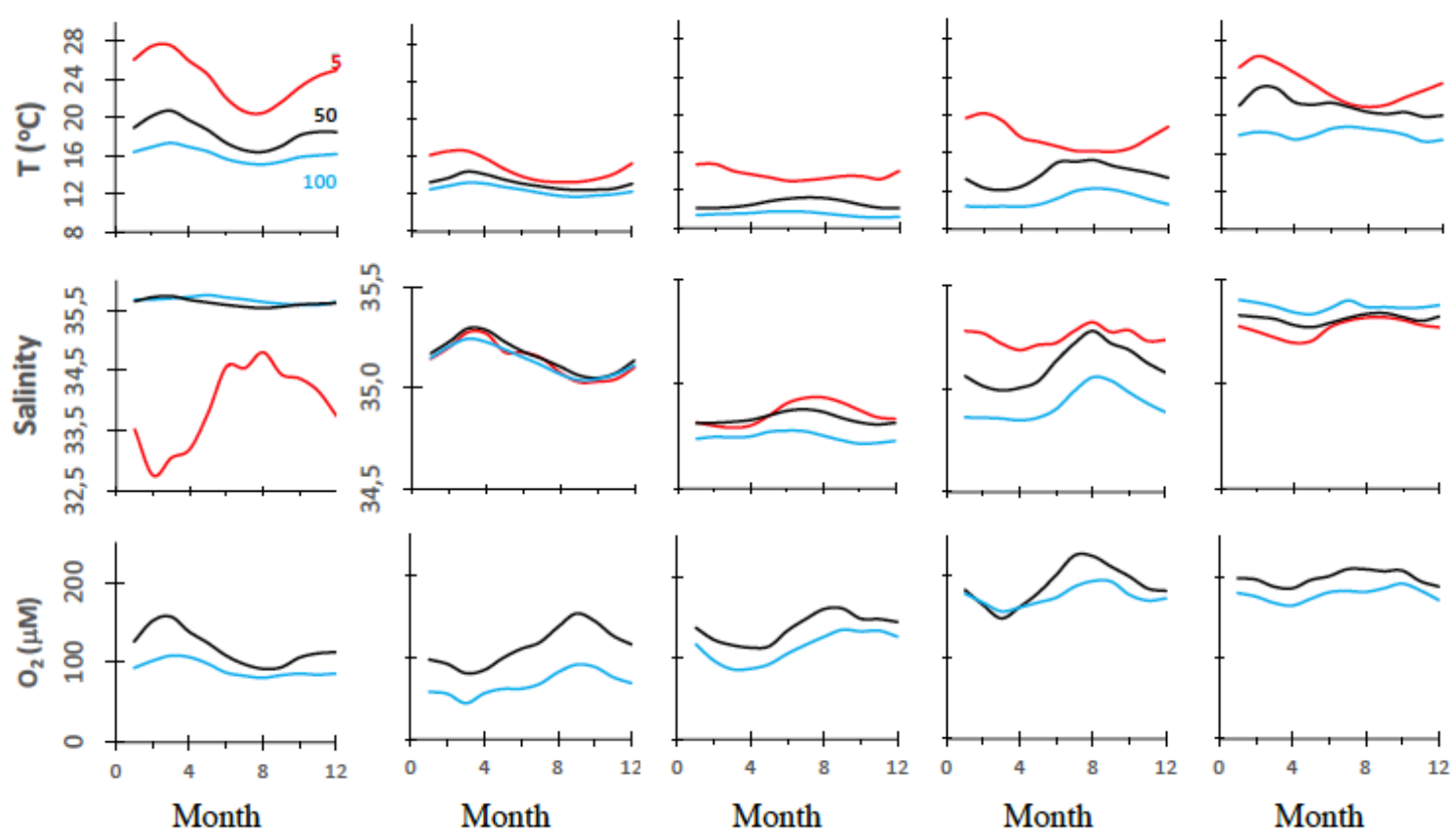

Fig 5. Composite temperature, salinity and oxygen annual profiles at depths of $5 \mathrm{~m}$ (red), $50 \mathrm{~m}$ (grey) and $100 \mathrm{~m}$ (blue), for all the $\mathrm{H}_{\text {coast }}$ bins within 5 degree sections. 
Table 1 Percentage of grid boxes requiring gap-filling $(n<3)$, for calculation of temperature at $50 \mathrm{~m}$ depth.

\begin{tabular}{|c|c|c|c|c|c|}
\hline AREA & $\begin{array}{c}\mathrm{H}_{\text {coast }} \\
\text { Monthly \% }\end{array}$ & Season & $\begin{array}{c}\mathrm{H}_{\text {coast }}-\mathrm{H}_{1.5^{\circ}} \\
\text {. }\end{array}$ & $\begin{array}{c}\mathrm{H}_{2^{\circ}}-\mathrm{H}_{3^{\circ}} \\
\%\end{array}$ & $\begin{array}{c}\text { Q1-Q6 } \\
\%\end{array}$ \\
\hline $\begin{array}{l}\text { West Coast: } \\
0-17^{\circ} \mathrm{S}\end{array}$ & 7 & $\begin{array}{l}\text { JFM } \\
\text { AMJ } \\
\text { JAS } \\
\text { OND }\end{array}$ & $\begin{array}{c}10 \\
6 \\
2 \\
0\end{array}$ & $\begin{array}{l}51 \\
32 \\
36 \\
17\end{array}$ & $\begin{array}{l}29 \\
29 \\
22 \\
19\end{array}$ \\
\hline $\begin{array}{l}\text { West Coast: } \\
17-28^{\circ} \mathrm{S}\end{array}$ & 0 & $\begin{array}{l}\text { JFM } \\
\text { AMJ } \\
\text { JAS } \\
\text { OND }\end{array}$ & $\begin{array}{l}0 \\
0 \\
2 \\
2\end{array}$ & $\begin{array}{l}11 \\
38 \\
41 \\
27\end{array}$ & $\begin{array}{l}1 \\
6 \\
6 \\
7\end{array}$ \\
\hline $\begin{array}{l}\text { West Coast: } \\
28-34.5^{\circ} \mathrm{S}\end{array}$ & 4 & $\begin{array}{l}\text { JFM } \\
\text { AMJ } \\
\text { JAS } \\
\text { OND }\end{array}$ & $\begin{array}{l}0 \\
2 \\
0 \\
2\end{array}$ & $\begin{array}{l}14 \\
33 \\
21 \\
33\end{array}$ & $\begin{array}{l}0 \\
2 \\
6 \\
8\end{array}$ \\
\hline $\begin{array}{l}\text { South Coast: } \\
18.5-26.5^{\circ} \mathrm{E}\end{array}$ & 5 & $\begin{array}{l}\text { JFM } \\
\text { AMJ } \\
\text { JAS } \\
\text { OND }\end{array}$ & $\begin{array}{l}8 \\
4 \\
2 \\
4\end{array}$ & $\begin{array}{l}23 \\
21 \\
26 \\
17\end{array}$ & $\begin{array}{c}16 \\
7 \\
10 \\
6\end{array}$ \\
\hline $\begin{array}{l}\text { East Coast: } \\
27-34.5^{\circ} \mathrm{S}\end{array}$ & 8 & $\begin{array}{l}\text { JFM } \\
\text { AMJ } \\
\text { JAS } \\
\text { OND }\end{array}$ & $\begin{array}{l}19 \\
15 \\
13 \\
25\end{array}$ & $\begin{array}{l}>50 \\
>50 \\
>50 \\
>50\end{array}$ & $\begin{array}{l}56 \\
30 \\
35 \\
51\end{array}$ \\
\hline $\begin{array}{l}\text { East Coast: } \\
10-27^{\circ} \mathrm{S}\end{array}$ & 25 & $\begin{array}{l}\text { JFM } \\
\text { AMJ } \\
\text { JAS } \\
\text { OND }\end{array}$ & $\begin{array}{l}13 \\
17 \\
17 \\
36\end{array}$ & $\begin{array}{l}>50 \\
>50 \\
>50 \\
>50\end{array}$ & $\begin{array}{l}>50 \\
>50 \\
>50 \\
>50\end{array}$ \\
\hline $\begin{array}{l}\text { East Coast: } \\
0-10^{\circ} \mathrm{S}\end{array}$ & 33 & $\begin{array}{l}\text { JFM } \\
\text { AMJ } \\
\text { JAS } \\
\text { OND }\end{array}$ & $\begin{array}{l}18 \\
20 \\
12 \\
23\end{array}$ & $\begin{array}{l}>50 \\
>50 \\
>50 \\
>50\end{array}$ & $\begin{array}{l}>50 \\
>50 \\
>50 \\
>50\end{array}$ \\
\hline
\end{tabular}

\subsection{Analysis of potential sampling bias related to time of day or inter-annual trends}

Evaluation of data distribution per time of day showed that $20 \%$ of the total casts were taken between 00:00 an 05:59 in the early morning, 32\% between 06:00 and 11:59, 28\% between $12: 00$ and 17:59 and 20\% between 18:00 and 23:59 (Appendix 1). This fairly even distribution of sampling during the 24 hour cycle was further explored for potential bias, as follows: a diurnal surface temperature profile was constructed for each season, consisting of twelve 2-hour average values, for every $\mathrm{H}$ bin with a total of more than 400 casts (Appendix 3). The temperature average obtained from the diurnal profile ( $\left.T_{\text {diurnal }}\right)$ was then compared to the average of all the values in the bin $\left(T_{\text {all }}\right)$, for each season, without consideration of sampling time, and yielded the following relationship:

$$
\mathrm{T}_{\text {all }}=0.9948^{*} \mathrm{~T}_{\text {diurnal }}+0.0827\left(\mathrm{r}^{2}=0.9988\right) \text {, and }
$$

$$
\left(T_{\text {all }}-T_{\text {diurnal }}\right)_{\text {average }}=-0.003^{\circ} \mathrm{C}+/-0.105(1 \sigma) \text {. }
$$

This analysis showed that there is no appreciable sampling bias related to the time of day, for surface temperature. It is also worth noting that the $12: 00$ to 17:59 period was the warmest time of the day (at the surface) in only $42.5 \%$ of the cases evaluated (Appendix 3 ). It is assumed that the time of day can also be ruled out as a potential appreciable source of sampling bias at 50 and $100 \mathrm{~m}$ depths, and for salinity and oxygen. 
The uneven spatial and temporal distribution of data across the study area (Fig 1A; Appendix 1) presents a challenge to the analysis of the data for potential inter-annual or inter-decadal trends or periodicity. Even in the relatively small geographic area with the largest number of casts over the longest period of time, i.e. between 32 and $34^{\circ} \mathrm{S}$ on the West Coast, time series consisting of one or two year average values revealed no statistically significant monotic trends or periodicity in temperature, salinitiy or oxygen. As an alternative, time series consisting of decadal average values were constructed, for 1945-1953 to 2005-2014, for each season and depth interval. A Mann-Kendall test was then performed on each constructed time series that comprised of at least 4 decadal values, as a test for monotic trends. Only $3.5 \%$ of the $\mathrm{H}_{\text {coast }}$ to $\mathrm{H}_{3}{ }^{\circ}$ bins contained enough data, over a long enough period and without too many sampling gaps, to satisfy this requirement. All significant monotic trends (>95\% confidence level) are listed in Table 2 and the relevance of these trends are discussed in the text. All of the East Coast $\mathrm{H}$ bins north of $33^{\circ} \mathrm{S}$ contained inadequate data for inclusion in this analysis.

Although the available data was too sparse for the robust statistical analysis of periodicity using spectral analysis, the decadal time series data suggested potentially interesting periodicities in the data, generally consistent with the Atlantic multidecadal oscillation (AMO), i.e. alternating periods of warm and cold sea-surface temperatures with a period of 60 to 90 years (Kerr, 2000; Knudsen et al., 2011). This motivated the construction of three 25 year climatologies (detailed in the next sub-section), for the periods 1945 to 1969,1970 to 1994 and 1995 to 2019, as an alternative evaluation of long-term variability. These 25 year periods approximate the timing of one cold (1970-1994) and two warm (19451969 and 1995-2019) phases of the AMO cycle. It also conveniently divided the data for the West and South coast areas into three equal 25 year periods, each with adequate data for the construction of climatologies at depths of 5,50 and $100 \mathrm{~m}$.

Table 2 Results of Mann-Kendall tests on decadal time series data for temperture and salinity. Trends shown are significant at the $>95 \%$ level, positive values (bold) indicate increases over time and negative values decreasing trends.

\begin{tabular}{|c|c|c|c|c|c|c|c|c|c|c|}
\hline Long & Lat & \multirow[t]{2}{*}{ Type } & \multirow[t]{2}{*}{ Season } & \multirow[t]{2}{*}{ Data Period } & $T-5$ & $\mathrm{~T}-50$ & $T-100$ & S-5 & S-50 & S-100 \\
\hline \multicolumn{2}{|c|}{$\left( \pm 0,25^{\circ}\right)$} & & & & \multicolumn{3}{|c|}{${ }^{\circ} \mathrm{C} /$ year } & \multicolumn{3}{|c|}{ units/year } \\
\hline 11,25 & $-5,25$ & $\mathrm{H} 2$ & JFM & 1960-1988 & $-0,014$ & & $-0,026$ & & & \\
\hline 13,25 & $-12,25$ & $\mathrm{H} 2$ & JFM & 1961-1999 & 0,050 & & & & & \\
\hline 12,25 & $-20,25$ & H3 & JFM & $1950-2002$ & 0,022 & & & & & \\
\hline 14,75 & $-25,75$ & $\mathrm{H} 1$ & JFM & $1966-1999$ & 0,033 & 0,037 & & 0,007 & 0,005 & 0,007 \\
\hline 18,25 & $-33,75$ & $\mathrm{H} 1$ & JFM & $1951-2008$ & & & 0,016 & & & 0,002 \\
\hline 19,25 & $-34,75$ & $\mathrm{H} 2$ & JFM & 1948-2007 & & 0,079 & & & 0,006 & \\
\hline 19,75 & $-34,75$ & $\mathrm{H} 1$ & JFM & 1948-2007 & & 0,127 & & 0,006 & 0,010 & \\
\hline 12,75 & $-20,75$ & $\mathrm{H} 2$ & AMJ & 1961-1999 & 0,026 & & & & & \\
\hline 13,75 & $-23,25$ & $\mathrm{H} 2$ & AMJ & $1961-2018$ & 0,033 & 0,020 & 0,017 & & 0,002 & \\
\hline 13,75 & $-23,75$ & $\mathrm{H} 2$ & AMJ & $1968-2018$ & 0,076 & 0,039 & & & 0,003 & 0,003 \\
\hline 17,25 & $-32,25$ & H3 & AMJ & 1948-2010 & $-0,027$ & $-0,022$ & $-0,016$ & & $-0,002$ & $-0,002$ \\
\hline 17,75 & $-34,25$ & $\mathrm{H} 2$ & AMJ & $1954-2008$ & 0,049 & 0,035 & 0,030 & & 0,003 & \\
\hline 23,25 & $-34,25$ & $\mathrm{H} 1$ & AMJ & 1958-2008 & $-0,040$ & & & & & \\
\hline 25,25 & $-34,25$ & $\mathrm{H} 1$ & AMJ & $1958-2008$ & $-0,023$ & & & & & \\
\hline 13,25 & $-21,25$ & $\mathrm{H} 2$ & JAS & 1959-1998 & 0,029 & & 0,020 & & 0,002 & 0,002 \\
\hline 16,75 & $-32,75$ & $\mathrm{H} 4$ & JAS & $1950-2011$ & 0,016 & 0,013 & & & & \\
\hline 18,25 & $-33,75$ & $\mathrm{H} 1$ & JAS & $1950-2008$ & 0,027 & 0,061 & 0,020 & & & 0,002 \\
\hline 17,75 & $-33,75$ & $\mathrm{H} 2$ & JAS & 1949-2004 & 0,022 & 0,053 & 0,034 & 0,003 & 0,005 & 0,004 \\
\hline 17,75 & $-34,25$ & $\mathrm{H} 2$ & JAS & $1950-2008$ & 0,020 & & & & 0,002 & \\
\hline 13,25 & $-23,25$ & $\mathrm{H} 3$ & OND & 1964-1999 & $-0,039$ & & & 0,003 & & \\
\hline 14,25 & $-23,75$ & H1 & OND & 1945-1999 & $-0,018$ & & & & & \\
\hline 19,25 & $-35,25$ & $\mathrm{H} 3$ & OND & $1948-2008$ & & & 0,024 & & & \\
\hline
\end{tabular}




\subsection{Construction of seasonal and annual climatologies}

The calculation of seasonal average values for $\mathrm{H}$ bins reduced the amount of gap-filling required considerably, compared to that required for monthly values (Table 1). The lower temporal sampling resolution (that is seasonal as opposed to monthly) then allowed for increased spatial resolution within the following data rich $\mathrm{H}$ bins, through their subdivisioning into $0.25^{\circ} \times 0.25^{\circ}$ (or Q) bins: $\mathrm{H}_{\text {coast }}$ and $\mathrm{H}_{1}{ }^{\circ}$ along the Gabon-Angola shelf, $\mathrm{H}_{\text {coast }}$ to $\mathrm{H}_{1.5^{\circ}}$ along the Central and Southern Benguela shelf and the Agulhas Bank, and $\mathrm{H}_{\text {coast }}$ along the East Coast, from 34.5 to $28^{\circ} \mathrm{S}$. Along the West and South coasts, seasonal average values were calculated for each of the three variables $\left(\mathrm{T}, \mathrm{S}\right.$ and $\left.\mathrm{O}_{2}\right)$ at depths of 5 , 50 and $100 \mathrm{~m}$, for the $\mathrm{Q}$ bins inside these $\mathrm{H}$ bins, and for the appropriate $\mathrm{H}_{\text {coast }}$ to $\mathrm{H}_{3^{\circ}}$ bins along the shelf areas outside of these $\mathrm{H}$ bins. Along the East Coast, seasonal values were calculated for temperature only. The mixed spatial resolution grid used to construct climatologies took cognizance of the variable continental shelf width of the study area, data density and the observation that in most areas data availability decreases substantially offshore of the $500 \mathrm{~m}$ isobath. For gap filling purposes, mean values for "empty" data bins $(\mathrm{n}<3)$ were calculated from the four nearest data bins, the pair of bins to the west and east, and that to the north and south. Along the West and South coasts "empty" data bins were usually isolated from each other and gap filling was straightforward. Along the East Coast, however, the larger proportion of "empty" data bins (Table 1) usually required an iterative process, starting with the filling of "empty" bins surrounded by at least 3 or 4 bins containing data, followed by the filling of empty bins surrounded by 2 bins containing data in addition to perhaps 1 or 2 gap-filled bins, and lastly empty bins surrounded by at least 1 data bin and 2 to 3 gap-filled data bins.

After construction of the seasonal climatologies, based on all data from 1945 to 2019 (Fig 6, 7, 8), annual climatologies consisting of the average of the seasonal values were constructed (Fig 9). Along the East Coast, the annual climatologies for salinity and oxygen represent the average of all available data. This procedure was then repeated to construct annual climatologies for the West and South coast areas, representing the 1945-1969, 1970-1994 and 1995-2019 periods mentioned earlier, but at a $0.5^{\circ}$ scale, i.e. using $\mathrm{H}$ bins only. Differentials were calculated from the 25 year climatological averages, and mapped as follows for temperature, (Fig 10), and similarly for salinity (Fig 11) and oxygen (Fig 12).
A to C: $\operatorname{Avg}_{\left.[1970 \text { to } 1994]-\operatorname{Avg}_{[1945} \text { to } 1969\right]}$
$D$ to $F: \operatorname{Av}_{\text {[1995 to } 2019]}-\mathrm{Avg}_{[1970 \text { to } 1994]}$
G to I: $\operatorname{Avg}_{[1995}$ to 2019$]-\operatorname{Avg}_{[1945}$ to 1969$]$
J to L: Avg[1995 to 2019] - Avg[1945 to 1969]\#, with \# indicating the exclusive plotting of $\mathrm{H}$ bins for which 25 year climatological values are available for each of the three 25 year periods, and that display monotonic trends (increasing or decreasing) from 1945 to 2019.

The standard deviation associated with the average of all of the data (1945 to 2019) within each $\mathrm{H}$ or $Q$ was mapped, as well as the standard deviation asssociated with the average of the seasonal values (Appendix 4). These statistics represent different types of variability within the data set, i.e. the total variability in the data and the variability around the seasonal average, and are not equivalent. All climatologies were plotted using the ODV free software package (Schlitzer, 2018). The "quick gridding" 
display option was used, since it produced the most realistic and least distorted data displays. The construction and visualization of the climatologies presented in this study are purposefully simplistic, in order to encourage its use, reproduction and modification.

\section{INTRA-ANNUAL VARIABILITY ALONG THE SOUTHERN AFRICA CONTINENTAL SHELF}

\subsection{Gabon to Angolan shelf, from the equator to $\sim 17^{\circ} \mathrm{S}$ on the West Coast}

Along the southern Africa shelf, the largest seasonal surface temperature fluctiations are observed on the shelf area between Gabon and Angola (or the Northern Benguela) (Fig 3A, 5). It is also only along the Gabon-Angola and the Central Benguela shelf areas that similar seasonal temperature profiles are observed at depths of 5, 50 and $100 \mathrm{~m}$ (Fig 5). These two adjacent areas also display similar temperature seasonality, or occurrence of the warmest and coldest periods of the annual cycle, and at all depths (Fig 4). During summer, the shelf area north of $\sim 12^{\circ} \mathrm{S}$ is characterized by water temperatures exceeding $28^{\circ} \mathrm{C}$, and very strong temperature gradients are present south of that towards the $20^{\circ} \mathrm{C}$ isotherm (Fig 3A, 6A). Apart from this, $>28^{\circ} \mathrm{C}$ surface water temperatures are observed on the shelf only in autumn (Fig 6B). The inner Angolan shelf area is dominated by 24 to $26^{\circ} \mathrm{C}$ surface water in autumn and spring, and 20 to $22^{\circ} \mathrm{C}$ in winter (Fig 6C, 6D). At $50 \mathrm{~m}$ depth an intrusion of warm water $\left(>20^{\circ} \mathrm{C}\right.$ ) is evident along the Gabon-Angola shelf, that appears to initiate near the equator in spring, and penetrates as far south as $12^{\circ} \mathrm{S}$ in summer, before it retreats or dissipates in autumn (Fig 6E-H). A similiar seasonal intrusion of warm water $\left(\left(>16^{\circ} \mathrm{C}\right)\right.$ is observed at $100 \mathrm{~m}$ (Fig 6I-L). The seasonal incursion of warmer water observed in the climatologies, supports the proposed strengthening of the Gabon-Congo Undercurrent (GCUC) during spring (Stramma and Schott, 1999). The GCUC flows southwards along the African coast and derives primarily from the Equatorial Under Current between $1^{\circ} \mathrm{S}$ and $6^{\circ} \mathrm{S}$ (Stramma and Schott, 1999).

Surface water on the Gabon-Angola shelf is significantly influenced by fresh water outflow from several large rivers, most notably the Congo River, the largest river along the southern Africa coastline (Fig 1A, 5). This results in large seasonal variability, and pronounced salinity gradients at the surface and between the surface and water at 50 and $100 \mathrm{~m}$ (Fig 5). The surface salinity climatologies show that the Congo river plume influences a very large part of the shelf in summer (Fig 7A) and reaches its smallest extent in winter (Fig 7C). This is consistent with Congo river seasonal flow fluctuations (Sonwa et al., 2020). Similar seasonal changes in salinity, but of smaller magnitude, just south of the equator and at $\sim 8^{\circ} \mathrm{S}$, presumably reflect the influences of the Ogooue river in Gabon and the Cuanza river in Angola, respectively.

The Gabon-Angola shelf area is also characterized by pronounced spatial and seasonal changes in dissolved oxygen, particularly at depths of 50 and $100 \mathrm{~m}$ (Fig 5, 8E-L). The oxygen climatologies show generally decreasing values from the equator towards the Angolan shelf. At $100 \mathrm{~m}$ depths, low oxygen water $\left(<100 \mu \mathrm{M} \mathrm{O}_{2}\right)$ water dominates the shelf between $5^{\circ} \mathrm{S}$ and $17^{\circ} \mathrm{S}$ throughout the year (Fig 8I-L). At both 50 and $100 \mathrm{~m}$ depth there is a westward and northward expansion of $<100 \mu \mathrm{M} \mathrm{O}_{2}$ water from summer (Fig 8E, 8I) to winter (Fig 8G, 8K). During summer, $<100 \mu \mathrm{M} \mathrm{O}_{2}$ water is situated offshore of the Angola shelf at $50 \mathrm{~m}$ depth (Fig 8E), as is the case for $<50 \mu \mathrm{M} \mathrm{O}$ water at $100 \mathrm{~m}$ depth (Fig 8I). This climatological observation of a minimum in the westward and northward extension of low oxygen water in summer, and a maximum extension of this water in winter, is consistent with previous reports for this area (Chapman and Shannon, 1987; Mohrholz et al., 2008). 


\subsection{Central and Southern Benguela shelf, from $\sim 17^{\circ} \mathrm{S}$ to $35^{\circ} \mathrm{S}$ on the West Coast}

Along the southern African shelf area, the smallest seasonal temperature ranges, at all depths, are

4 observed in the climatologies of the Southern Benguela ( 28 to $36^{\circ} \mathrm{S}$ ) inner shelf, and the Central Benguela ( 17 to $28^{\circ} \mathrm{S}$; Fig 3,5 ). At $\sim 27^{\circ} \mathrm{S}$ and $32^{\circ} \mathrm{S}$, where the shelf is at its broadest (Fig $1 \mathrm{~A}$ ), summer surface temperatures are higher and the seasonal temperature range larger, compared to adjacent shelf areas (Fig 3A). A notable feature of seasonal temperature variability in the Southern Benguela is that temperature moves out of phase with increasing depth (Fig 4, 5). At 50 and $100 \mathrm{~m}$ depths, temperature is higher during the winter than during spring and summer, the opposite to what is observed at the surface. This result is consistent with the seasonal Southern Benguela upwelling season, which peaks in spring and summer (Hutchings et al., 2009) and is associated with the upwelling of colder (and lower salinity) water onto the shelf. Upwelling processses in the Central and Southern Benguela have been extensively studied and there are numerous publications and reports that can be consulted for much more detail than the space in this manuscript allows for ( Hutchings et al., 2009, and reference therein; Jarre et al., 2015b; Lamont et al., 2018).

Seasonal climatologies show that surface temperature values below $16^{\circ} \mathrm{C}$ (as an example) is a persistent feature along the inner shelf along the Central and Southern Benguela in spring and autumn (Fig 6B, 6D). During summer, however, this $16^{\circ} \mathrm{C}$ surface isotherm contracts towards the coast and is absent from the northern half of the Central Benguela (Fig $6 \mathrm{~A}$ ). During winter, in contrast, $<16^{\circ} \mathrm{C}$ water extends much further westward, as well as further north and south than is observed in spring and autumn (Fig 6C). During winter, in fact, the surface $16^{\circ} \mathrm{C}$ isotherm extends beyond the Southern Benguela, in an eastward direction along the shelf to $\sim 22^{\circ} \mathrm{E}$ on the Agulhas Bank (Fig $6 \mathrm{C}$ ). Similarly, 16 to $18^{\circ} \mathrm{C}$ surface water is present in a continuous band that extends from the Central Benguela shelf to the eastern Agulhas Bank in spring and autumn (Fig 6B, 6D). In contrast, 16 to $18^{\circ} \mathrm{C}$ surface water is restricted to the Central and Southern Benguela and absent from the Agulhas Bank in summer, (Fig $6 \mathrm{~A})$, but absent from the Central and Southern Benguela, and present on the Agulhas Bank, in winter (Fig 6C). These seasonal contractions and expansions in the areal extent of water within specific temperature envelopes are also observed in the 50 and $100 \mathrm{~m}$ climatologies. At $100 \mathrm{~m}$ depth, for example, $<12^{\circ} \mathrm{C}$ is present on the shelf in a continous band than extends from the Southern Benguela, all the way to the eastern edge of the Agulhas Bank, in summer and autumn (Fig 6l, 6J). In winter (Fig $6 \mathrm{~L}$ ) and spring (Fig $6 \mathrm{~L}$ ), however, the $<12^{\circ} \mathrm{C}$ extends into the Central Benguela, at a depth of $100 \mathrm{~m}$. Also, in winter and spring, $<12^{\circ} \mathrm{C}$ water does not occur in a continous band from the Souther Benguela to the eastern Agulhas Bank at $100 \mathrm{~m}$, due to the presence of warmer water between $\sim 20$ and $22^{\circ} \mathrm{E}$ during these seasons.

In the Central Benguela, seasonal salinity climatologies (for 5, 50 and $100 \mathrm{~m}$ ) suggest a southward shift in the position of the salinity isolines in the northern part of the Central Benguela shelf $(\sim 17$ to $22^{\circ} \mathrm{S}$, Fig 7), consistent with the southward migration of the $A B F$, and the higher salinity and low oxygen water associated with it, from February to April (Dias, 1983; Stramma and Schott, 1999; Ekau and Verheye, 2005; Mohrholz et al., 2008). The Southern Benguela shelf is characterized by the lowest salinity waters on the southern African shelf, with the obvious exception of surface water on the GabonAngolan shelf (Fig 5). The surface salinity climatologies show a freshwater influence at the Orange river mouth $\left(\sim 28.5^{\circ} \mathrm{S}\right)$ and at the Berg river mouth $\left(\sim 32.5^{\circ} \mathrm{S}\right)$ (Fig 7A-D). This is more pronounced in 
summer and winter respectively, consistent with the peak runoff seasons of these rivers (de Villiers and Thiart, 2007). Apart from these river influences, the lowest salinity waters are found at $100 \mathrm{~m}$ depth, and during summer (Fig 7l) and autumn (Fig 7J). Enhanced freshening of water during summer and autumn are also observed at $50 \mathrm{~m}$ at $\sim 32^{\circ} \mathrm{S}$ in the Soutern Benguela. The seasonal salinity changes evident in the 50 and $100 \mathrm{~m}$ climatologies, are consistent with the seasonal upwelling of low salinity water onto the shelf (Hutchings et al., 2009).

Composite graphs of intra-annual variability in dissolved oxygen show that the Central Benguela is characterized by the lowest oxygen levels in the study area (Fig 5). In both the Central and Southern Benguela, oxygen levels decline during the summer and autumn, at both 50 and $100 \mathrm{~m}$ depths, and reach a seasonal high in winter. The seasonal oxygen climatologies show that the presence of low oxygen water $\left(<100 \mu \mathrm{M} \mathrm{O}_{2}\right)$ is widespread along the inner shelf at $100 \mathrm{~m}$ depth (Fig $8 \mathrm{I}-\mathrm{L}$ ) in both the Central and Southern Benguela. The areal extent of this low oxygen water is more widespread in summer and autumn, than in winter and spring. In the Central Benguela, these seasonal changes are more pronounced, and low oxygen water extends $\sim 2^{\circ}$ further south and futher offshore during summer and autumn. These seasonal changes are consistent with the seasonal incursion of low oxygyen water form the Angola Gyre into the Central Benguela, mentioned earlier (Dias, 1983; Stramma and Schott, 1999; Ekau and Verheye, 2005; Mohrholz et al., 2008) and documented seasonality in the Southern Benguela (Hutchiings et al., 2009; Jarre et al., 2015b). At $50 \mathrm{~m}$ depth, low oxygen water is less widespread than at $100 \mathrm{~m}$ (Fig 8E-H). In the Southern Benguela, low oxygen water is evident at $50 \mathrm{~m}$ in the summer, and at the $\sim 29^{\circ} \mathrm{S}$ and $\sim 32.5^{\circ} \mathrm{S}$ upwelling cells only (Fig $8 \mathrm{E}$ ). There is some indication of its presence, at $50 \mathrm{~m}$, at the $\sim 29^{\circ} \mathrm{S}$ upwelling cell in autumn (Fig $8 \mathrm{~F}$ ) and the $32.5^{\circ} \mathrm{S}$ cell in spring (Fig $8 \mathrm{H}$ ), but it is entirely absent from the Southern Benguela in winter (Fig 8G). Surface ocean oxygen levels (Fig 8A-D) vary seasonally in response to primarily changes in primary productivity and temperature, and a discussion of these complex processes and interpretation of these changes are beyond the scope of this manuscript.

\subsection{South Coast or Agulhas Bank, from $18.5^{\circ} \mathrm{E}$ to $26.5^{\circ} \mathrm{E}$}

A prominent commonality between the South Coast and the Southern Benguela, is the contrasting temperature seasonalities of surface and deeper waters (Fig 5). On the Agulhas Bank, as also observed in the Southern Benguela, water temperature at 50 and $100 \mathrm{~m}$ depths reaches a seasonal high in winter, and not in summer as is observed at the surface. On the Agulhas Bank, this difference in seasonality between surface and deeper waters is more pronounced than in the Southern Benguela. Temperature climatologies show that along the South Coast, surface temperature generally increases in an easterly direction (Fig 6A-D). Along the inner shelf, this general trend is disrupted in areas of coastal upwelling, for example between $\sim 23^{\circ}$ and $24^{\circ} \mathrm{E}$ in autumn (Fig 6B). During summer, the Agulhas Bank is dominated by surface water temperatures in the 20 to $22^{\circ} \mathrm{C}$ range (Fig $6 \mathrm{~A}$ ). From autumn to spring, however, the $20^{\circ} \mathrm{C}$ surface isotherm is situated along the eastern shelf edge of the Agulhas Bank, and the shelf is dominated by 16 to $20^{\circ} \mathrm{C}$ surface water (Fig $6 \mathrm{~B}-\mathrm{D}$ ). The $16^{\circ} \mathrm{C}$ surface isotherm migrates from its spring/summer inner shelf position at Cape Point $\left(\sim 18.5^{\circ} \mathrm{E}\right)$ to just west of Cape Agulhas $\left(\sim 20^{\circ} \mathrm{E}\right)$ in autumn and Cape Infanta $\left(\sim 21^{\circ} \mathrm{E}\right)$ in winter (Fig $\left.6 \mathrm{C}\right)$. At $100 \mathrm{~m}$ depth, cold $\left(<16^{\circ} \mathrm{C}\right)$ water is present along the inner shelf throughout the year, but it is more prominent and present in a continous band than extends into the Southern Benguela, in summer (Fig $6 \mathrm{l}$ ) and autumn (Fig 6J), 
as mentioned previously. Temperature climatologies suggest similar seasonalities are present at $50 \mathrm{~m}$ (Fig 6E-H).

Seasonal salinity climatologies (Fig 7), mirror that of temperature, with lower salinities coinciding

4 with colder temperatures, and higher salinities with higher temperatures. Seasonal oxygen climatologies (Fig 8) show that cold, lower salinity waters also typically have lower oxygen values, with similar seasonal variations to that observed for temperature and oxygen. Although Agulhas Bank water has higher $\mathrm{O}_{2}$ levels than that of the Southern Benguela shelf, ranging from 125 to $200 \mu \mathrm{M}$ at $100 \mathrm{~m}$ compared to 75 to $175 \mu \mathrm{M}$, it displays similar seasonality, with generally lower values in summer and autumn and to a lesser extent spring. The upwelling features and gradients across the Agulhas Bank, evident in the temperature, salinity and oxygen climatologies are consistent with previous observations of wind-driven coastal upwelling and shelf-edge upwelling induced by the southward flowing Agulhas Current (Probyn et al., 1994; Lutjeharms et al., 1996). The seasonal climatologies presented here provide new insight into the spatial extent of intra-annual variability and the connectivity with the Southern Benguela.

\subsection{East Coast, from the equator to $36^{\circ} \mathrm{S}$}

Despite the limitations resulting from relative data scarcity along the East Coast, some patterns are evident. Along the East Coast, there is a decrease in temperature, but a general increase in the seasonal surface temperature range from the equator towards the pole (Fig 3), which is opposite to the trend observed along the West Coast. Seasonal temperature profiles appear complex, particularly along the inner shelf and at $100 \mathrm{~m}$ depth (Fig 5). This may be an artefact of the relative scarcity of data on the East Coast, but it can also reflect high variability associated with the incursion of offshore waters onto the shelf, which is very narrow in some areas compared to the West and South Coast shelf areas. East Coast shelf water is consistently warmer than that of the West Coast at similar latitudes (Fig 3). For example, between 0 and $10^{\circ} \mathrm{S}$, East Coast shelf water is approximately 6 to $8^{\circ} \mathrm{C}$ warmer than that of the West Coast, at all three depths. Between 25 and $35^{\circ} \mathrm{S}$, this offset is 8 to $10^{\circ} \mathrm{C}$ at each of the three different depths.

It is evident in the seasonal surface climatologies that $>28^{\circ} \mathrm{C}$ water is much more common on the the East Coast, than on the West Coast, and it is present as far south as at least $25^{\circ} \mathrm{S}$ in summer (Fig $6 \mathrm{~A}$ ) and $15^{\circ} \mathrm{S}$ in autumn and spring (Fig 6B, 6D). In winter, however, the East Coast shelf is characterized by average surface temperatures below $26^{\circ} \mathrm{C}$ (Fig $6 \mathrm{C}$ ). The $24^{\circ} \mathrm{C}$ surface isotherm intersects the coastline at a relatively narrow latitudinal range of 25 to $27^{\circ} \mathrm{S}$ from autumn to spring, but extends much further south in summer. This southward summer shift coincides with the westward shift of the $20^{\circ} \mathrm{C}$ isotherm along the southern margin of the East Coast and the Agulhas Bank, and an apparent shelf-ward shift of offshore warm surface water during this season, possibly related to seasonality in the position of the Agulhas Current. An interesting feature of the temperature climatologies is the temperature maximum between 10 and $15^{\circ} \mathrm{S}$ along the East Coast, particularly noticeable at deeper depths (Fig 6D-H). The warmer shelf water between these latitudes is also characterized by lower salinity values, compared to shelf water further north and south.

Freshening of surface water is evident offshore of river mouths, for example the Tugela, Limpopo, Zambezi, Rufiji and Tana rivers (Fig 1, Fig7A-D). The geographic extent of the influence of these river outflows on the salinity of shelf surface water, however, is not as pronounced as that of the Congo river 
on the Angolan shelf area. Data scarcity impedes capture of such features in a climatology. The warm waters of the East Coast contain high oxygen levels with apparently low seasonal variability; the scarcity of oxygen data along the East Coast, however, precludes a more detailed discussion and evaluation of these observations.

\section{ENVIRONMENTAL CLIMATOLOGIES AND ECOLOGICAL CONSIDERATIONS}

4.1 Biogeographic zone boundaries in comparison to key climatological map features The approximate boundaries of biogeographic Realms and ecoregions blocks (Spalding et al., 2007), LME's (Sherman, 1993) and coastal biogeographic zones (Potts et al., 2015), were superimposed on the annual climatologies of temperature, salinity and oxygen, to qualitative evaluate biogeographic boundaries in the context of environmental spatial patterns (Fig 9). It is difficult to find qualitative agreement between the temperature, salinity and oxygen climatologies, and the large scale biogeographic zones, that is the Realms and LME's. If the Temperature Southern African Realm (Fig 2) extended $\sim 5^{\circ}$ further north, with its boundary with the Tropical Atlantic Realm positioned just north of the $A B F$, it would capture all southern African shelf water with average surface temperatures $\angle 24^{\circ} \mathrm{C}$. The smaller ecoregion blocks within these Realms (numbered in Fig 9 according to Spalding et al., 2007), however, also display poor qualitative agreement with environmental climatologies. An exception to this is the "Namaqua" ecoregion block (\#191 in Fig 2 and 9), which corresponds to the Southern Benguela (Fig 9). The LME divisions (Sherman, 1993) show the poorest relationship with environmental variables. The coastal biogeographic zones (Potts et al., 2015), overall, agree the best with features of the environmental climatologies. This classification scheme uniquely transends national boundaries, and also rely primarily on taxonomy (Briggs and Bowen, 2012; Potts et al. 2015; Whitfield, 2005). The tropical coastal zone corresponds with average surface water temperatures $>25^{\circ} \mathrm{C}$ on both the West and East Coast, the sub-tropical coastal zone with average surface values between $\sim 23$ and $25^{\circ} \mathrm{C}$ on both the West and East Coast, and the warm-temperate coastal zone with surface values between $\sim 17$ and $23^{\circ} \mathrm{C}$, on the West and South Coast (Fig 9A). The construction of climatologies for key ocean variables, and at the surface as well as deeper depths, can be used as a guide to refine the boundaries of biogeographic zones, or possibly to evaluate the usefulness of the concept of such boundaries in a highly variable environment.

\subsection{Decadal changes in environmental climatologies, compared to marine species range shifts} Differences between the three 25 year climatologies, representing changes and trends from 1945 to 2019, demonstrate the complexity and spatial heterogeneities inherent in environmental change, that have been the bugbear of efforts to understand increasing evidence for ecosystem change (Fig 10 to 12). For the sake of brevity, only the most prominent changes are summarized below, followed by a synopsis of documented environmental and ecosystem changes, that correspond to changes and trends evident in the environmental climatologies (Table 2; Fig 10-12): 1995-2019 periods. 
- Temperature change in the Central and Southern Benguela were generally out of phase with that on the Gabon-Angola shelf in 1970-1994, compared to 1945-1969, while the Agulhas Bank was in phase with the Gabon-Angola shelf during these periods.

4 - There is a general warming trend along the entire West Coast shelf area, at all depths; the only exceptions to this warming trend are observed at some of the upwelling areas, most notably parts of the Angolan shelf and the central part of the Southern Benguela.

7 - Warming is more pronounced in the Northern Benguela, than in the Central Benguela.

8 - There is a warming trend on the western Agulhas Bank, that contrasts with a cooling trend on the eastern Agulhas Bank; these trends are more prominent at deeper depths around the shelf edge. - Increasing temperature trends are generally accompanied by increasing trends in salinity, and cooling trends with decreasing trends in salinity.

- Dissolved oxygen levels are generally decreasing in the Central and Southern Benguela, and the Agulhas Bank, but there is evidence for increasing oxygen levels in the Northern Benguela.

The above climatological trends are consistent with documented changes in the environment, such as:

- Increasing trends in sea surface temperature off Angola over the past three decades, with above global average values (Hobday and Pecl, 2014; Bindoff et al., 2019) of between $0.23^{\circ} \mathrm{C}$ (Jarre et al., 2015a) and $0.8^{\circ} \mathrm{C}$ (Potts et al., 2014) per decade.

- Southward shifts of warm Angola-Benguela Front water by about $2^{\circ}$, in response to changes in the position of the South Atlantic High-Pressure Cell (Vizy et al., 2018).

- A decline in upwelling favourable winds in the Central Benguela, but increases in the Southern Benguela (Hutchings et al., 2009; Jarre et al., 2015; Van der Lingen and Hampton, 2018).

- A decline of upwelling off Namibia (Santos et al., 2012; Lamont et al., 2018) and coastal temperature increases of between 0.2 and $0.5^{\circ} \mathrm{C}$ per decade in the northern part of the Central Benguela (Jarre et al., 2015a).

- Cooling of inshore waters along South Africa's west and south coast by 0.1 to $0.2^{\circ} \mathrm{C}$ per decade over the past four decades, in contrast to warming of Agulhas Current water by up to $0.6^{\circ} \mathrm{C}$ per decade (Rouault et al., 2010; Blamey et al., 2015).

- Increased cooling and upwelling in the Southern Benguela (Rouault et al., 2010; Lamont et al.,

31 2018; Leduc et al., 2010; Santos et al., 2012).

32 - Broadening of the Agulhas Current (Beal and Elipot, 2015). Differences between the 25 year climatologies suggest that long-term cooling of the eastern Agulhas Bank is taking place (in areas of wind-induced coastal upwelling and along the shelf edge), with a contrasting warming trend on the western Agulhas Bank, that is on the "lee" side of the Agulhas Bank in relation to the flow direction of the Agulhas Current. The results suggest that the Agulhas Bank may be significantly impacted by the reported broadening of the Agulhas Current. The climatological trends are also consistent with documented ecosystem changes, such as:

40 - Decreased pelagic fish catches off Angola from the late 1970's to 1990's, with recoveries since the mid-2000's (Kainge et al., 2020). Oxygen has been shown to be a key determinant of species such 
as juvenile deepwater hake in the Northern Benguela (Kainge et al., 2017) and the climatologies document warmer temperature and higher oxygen levels, coinciding with the recovery of fisheries.

- An increase in the latitudinal range of demersal species off Angola, with an overall southward tendency and an expansion into deeper water (Yemane et al., 2014).

- A southward shift in the distribution of some Angolan coastal fish species (Potts et al., 2014)

- A southward shift for round herring in the Southern Benguela (Blamey et al., 2015).

- An eastward shift for adult anchovy (Roy et al., 2007; Fairweather et al., 2006) and sardine (Coetzee et al., 2008) since the mid-to-late-1990's (Augustyn et al., 2017).

9 10

- An eastward migration of rock lobster (Cockcroft et al., 2008).

There are several important caveats associated with the choice of 25 year periods for the construction of climatologies, that need to be emphasized. The choice of periods were primarily informed by the availability of data, for both the West and South Coast shelf areas. It is not the intention of this study to propose that these are the best or most ideal periods for the evaluation of decadal periodicities or long-term trends, or that the entire southern African shelf area is subject to decadal periodicities with similar amplitudes or periods. The choice of periods may not even be ideal for the evaluation of Gabon-Angola shelf waters, despite climatological evidence for AMO periodicities on the adjacent continental shelf and the ocean areas further north (Kerr, 2000; Knudsen et al., 2011; Sonwa et al., 2020). The most appropriate choice of time period for the study of trends or periodicities can only be informed by the availability of more data. These caveats, however, make the correspondence between changes observed in the climatologies, compared to documented and anticipated (Bakun et al., 2015; Bindoff et al., 2019) environmental and ecological changes, all the more remarkable. A speculative observation, based on the results of this study, is that decadal periodicities are in the process of being interrupted by a longer-term trend, possibly as the result of global warming.

\section{CONCLUSIONS}

This study raises several important issues in regards to marine species range shifts, in response to environmental change, and the definition of biogeographic zone boundaries. Ecological changes can only be fully understood and interpreted in an environmental context, if the environmental tolerances and ranges of species are known. Environmental climatologies, such as those presented here, can be used to guide the design of laboratory and field studies, for the optimal collection of data aimed at better understanding the environmental tolerance limits of species. The climatologies also shed important light on the geographic complexity of environmental change, that can be used to guide management decisions about geographic areas to prioritize for monitoring and conservation purposes. The climatologies also demonstrate that ecoregion or biogeographic boundaries cannot be assumed to occupy similar geographic locations for species that occupy different depth zones, and that changes observed at the surface cannot be assumed to apply to deeper depths.

Data availability is a concern, most obviously for the East Coast shelf area. There are two specific areas that appear curiously under-studied and under-sampled, given their oceanographic significance in the region: the Agulhas Current source region off southern Mozambique on the East Coast, and the large Lüderitz upwelling at $\sim 27^{\circ} \mathrm{S}$ on the West Coast. The Agulhas Bank has been more extensively studied than these two areas, but not nearly as extensively as the Southern Benguela; the magnitude 
1 of change evident for the Agulhas Bank in the climatologies should motivate more studies and

2 monitoring in this important transition zone. The most significant concern around data availability,

3 however, is that only $0.33 \%$ of the data used in this study represent sampling carried out since 2010

4 (Appendix 1). In some instances this reflects an actual reduction in ocean monitoring activities, but it

5 also reflects changing attitudes towards the placement of data in the public domain, even when data

6 collection is publicly funded. There is evidence for accelerated global environmental change since

7 2010, (Bindoff et al., 2019), that is not captured in the climatologies of this study, because of the dearth

8 of recent data in the public domain for the southern African shelf area. It remains to be seen, therefore,

9 to what extent the decadal changes presented in this study over- or under-represent present and on-

10 going change in the region.

\section{Acknowledgements}

The author is indebted to all the scientists, ship and laboratory assistants, ship crew members and database personnel that contributed to the collection, production and archiving of the data that this study is based on, and the institutions and individuals that motivated for the placement of this data in the public domain. The author did not receive financial assistance from any institution, entity or individual in support of this work. 


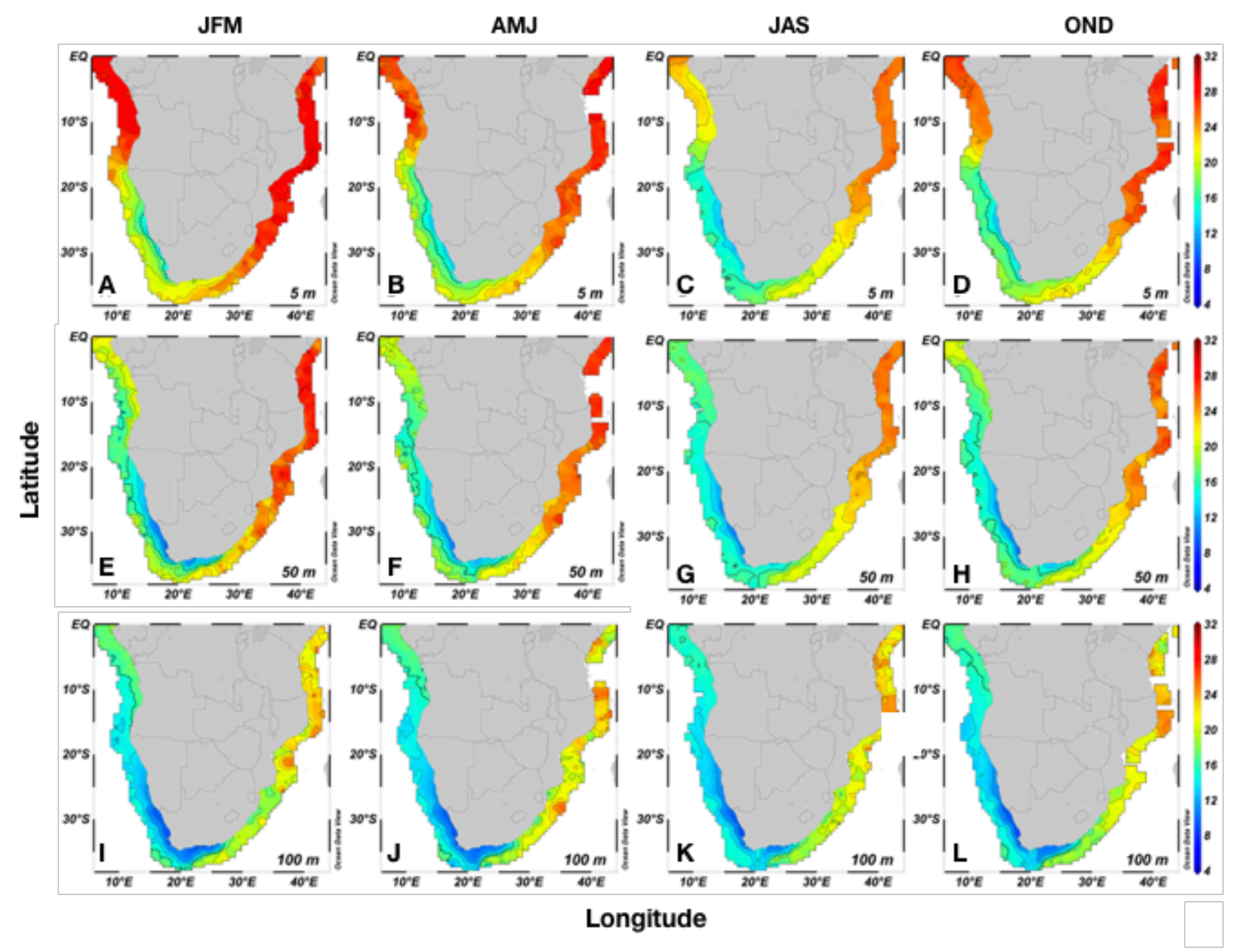

Fig 6. Seasonal temperature climatologies at depths of $5(A$ to $D), 50(E$ to $H)$ and $100 \mathrm{~m}(\mathrm{I}$ to $\mathrm{L})$ for summer (JFM), autumn (AMJ), winter (JAS) and spring (OND). Contour intervals are $2^{\circ} \mathrm{C}$, with $16^{\circ} \mathrm{C}$ indicated with a dashed line. 
1

2

3

4

5

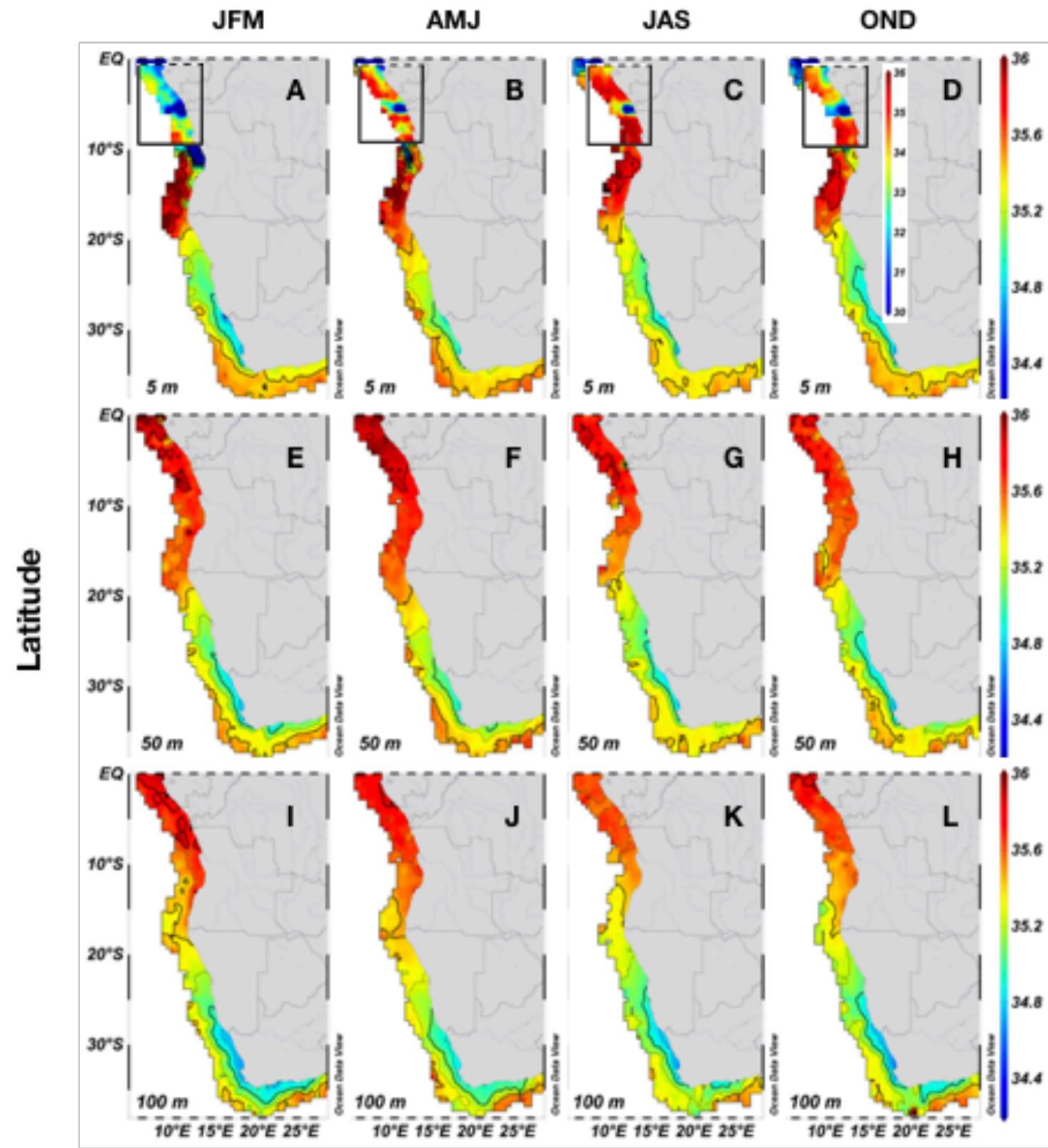

\section{Longitude}

Fig 7. Seasonal salinity climatologies at depths of 5 (A to $D), 50$ ( $E$ to $H$ ) and $100 \mathrm{~m}$ (I to $L$ ) for summer (JFM), autumn (AMJ), winter (JAS) and spring (OND). Contour intervals are 0.2, with 34.6, 35.0 and 35.4 indicated with thicker lines. 


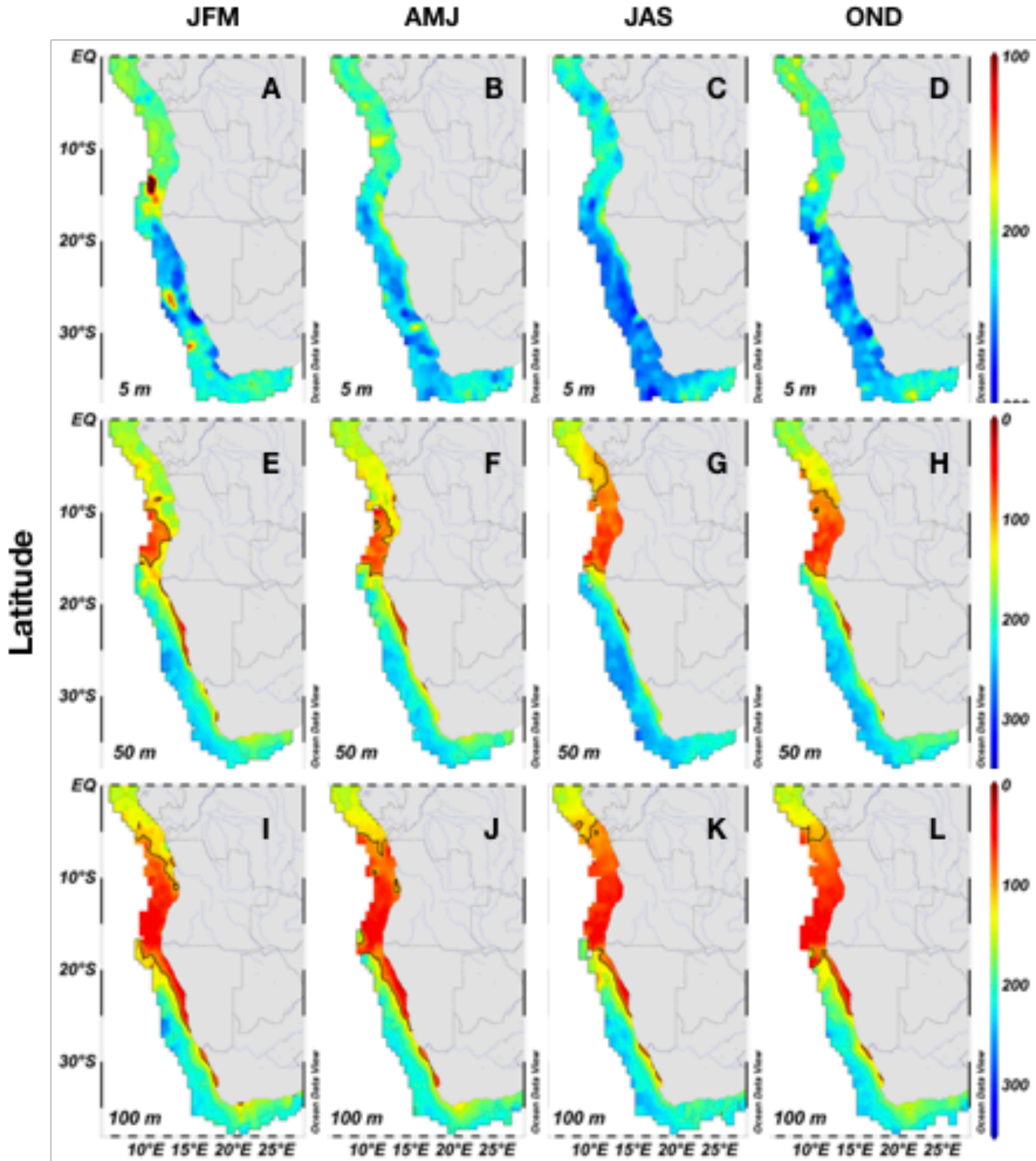

\section{Longitude}

Fig 8. . Seasonal oxygen climatologies at depths of $5(A$ to $D), 50(E$ to $H)$ and $100 \mathrm{~m}(\mathrm{I}$ to $\mathrm{L})$ for summer (JFM), autumn (AMJ), winter (JAS) and spring (OND). Contour intervals are $50 \mu \mathrm{M}$, with 100 $\mu \mathrm{M}$ indicated with a thicker line. 


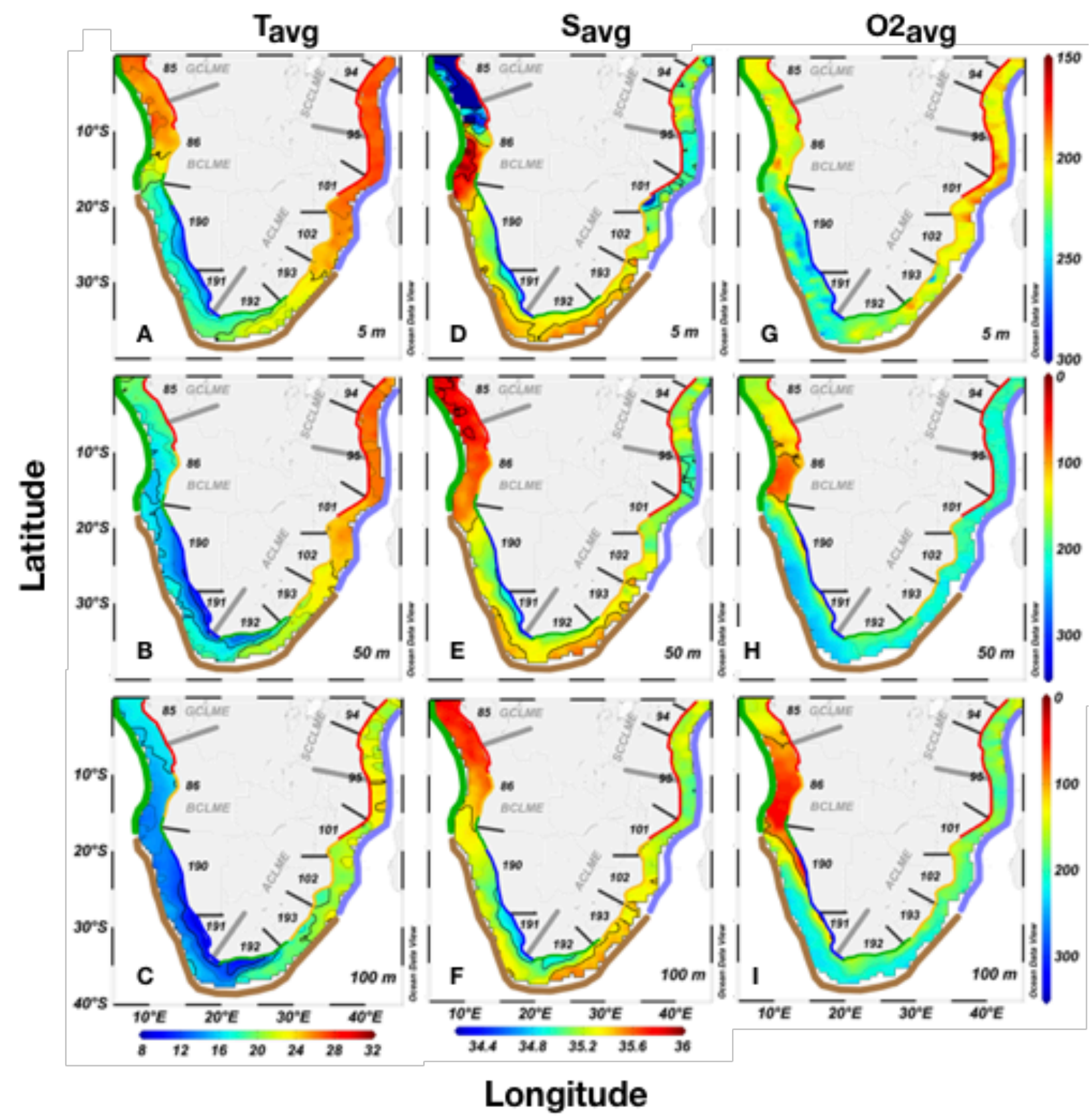

Fig 9. Annual climatologies for temperature ( $A$ to $C$ ), salinity ( $D$ to $F$ ) and oxygen ( $G$ to $I$ ), at depths of 5,50 and $100 \mathrm{~m}$ depths. Temperature contour intervals are $2^{\circ} \mathrm{C}$, with 16,20 and $24^{\circ} \mathrm{C}$ indicated with thicker lines. Salinity contour intervals are 0.2 , with $34.6,35.0$ and 35.4 indicated with thicker lines. Oxygen contour intervals are $50 \mu \mathrm{M}$ and $100 \mu \mathrm{M}$ is indicated with a thicker line. The biogeographic boundaries of Fig 2 are superimposed on the climatologies. 


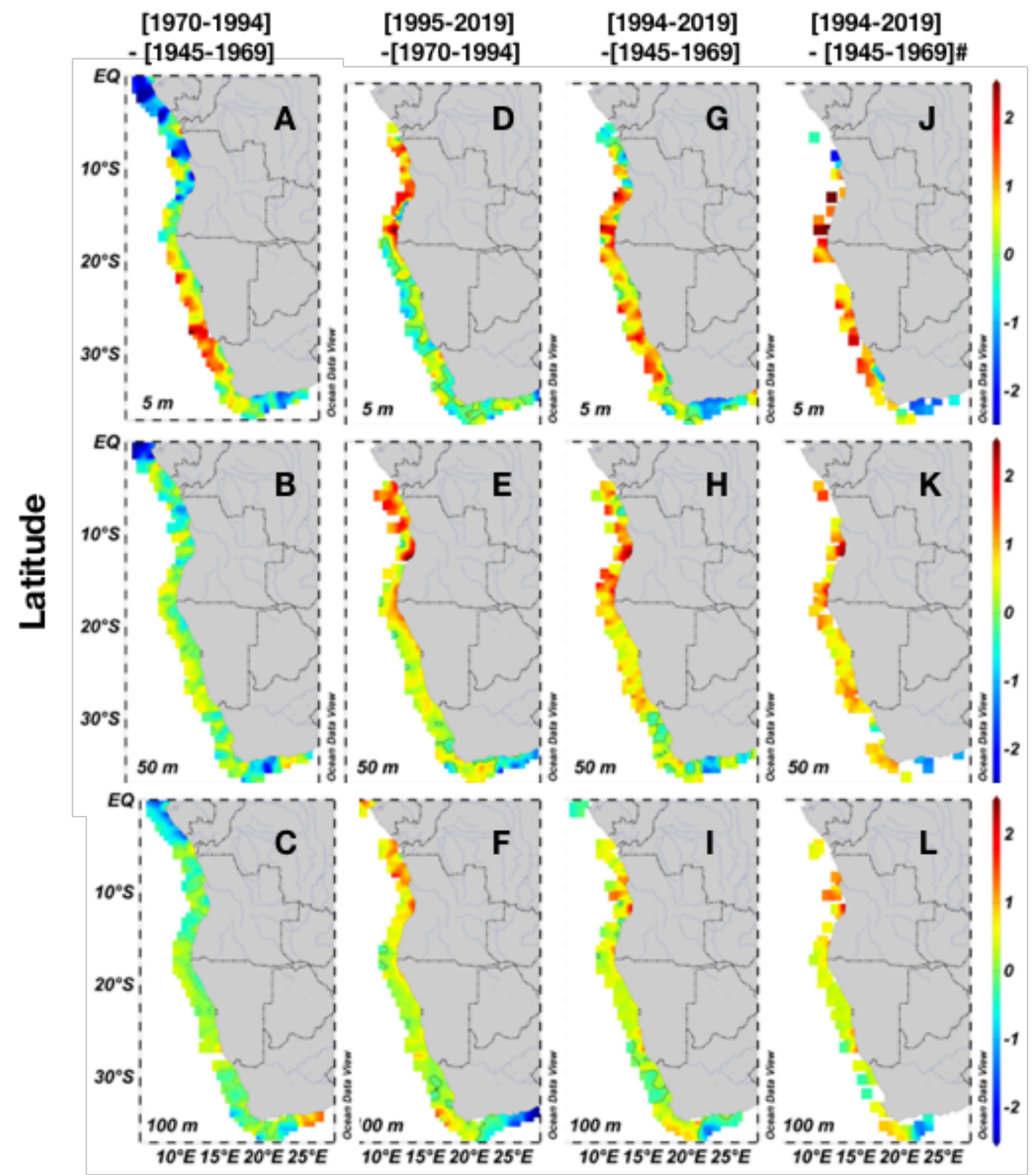

\section{Longitude}

Fig 10. The difference between 25 year climatological average annual temperature values ( $T_{25 y r}$ period $)$

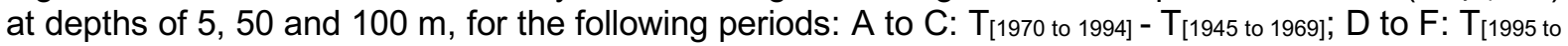

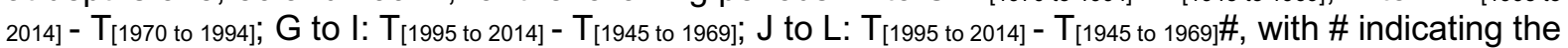
exclusive plotting of $\mathrm{H}$ bins for which 25 year climatological values are available for each of the three 25 year periods, and that display monotonic trends (increasing or decreasing) from 1945 to 2014 . The zero contour line is shown. 


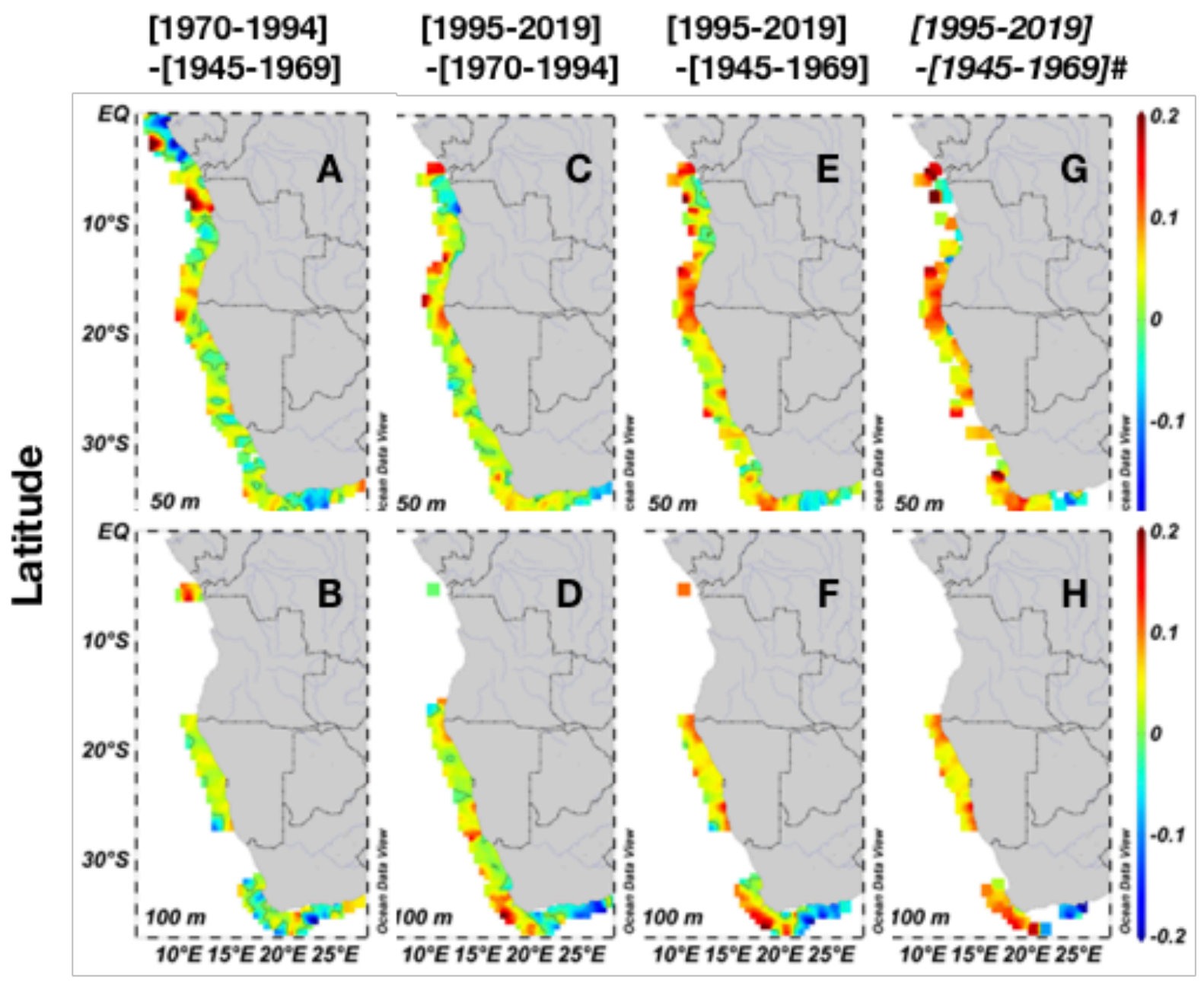

\section{Longitude}

Fig 11. The difference between 25 year climatological average annual salinity values $\left(S_{25 y r}\right.$ period $)$ at

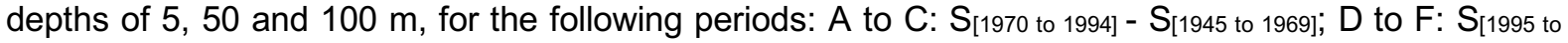

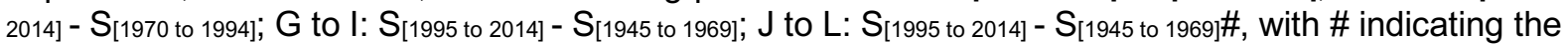
exclusive plotting of $\mathrm{H}$ bins for which 25 year climatological values are available for each of the three 25 year periods, and that display monotonic trends (increasing or decreasing) from 1945 to 2014. The zero contour line is shown. 


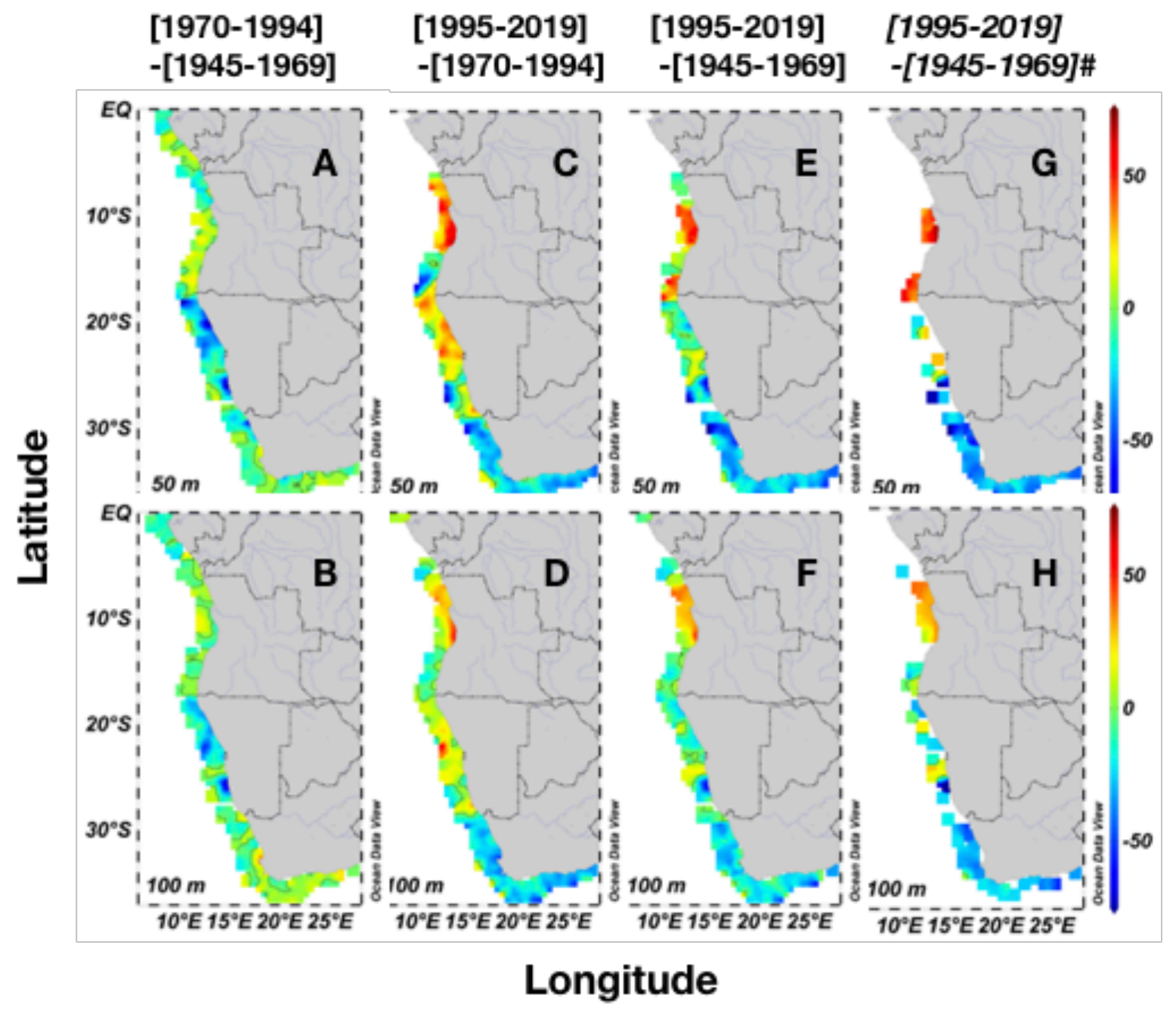

Fig 12. The difference between 25 year climatological average annual oxygen values $\left(\mathrm{O}_{25 y r}\right.$ period $)$ at

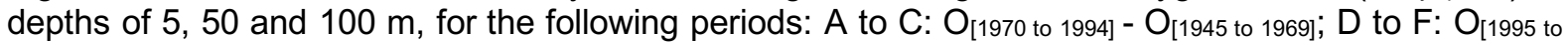

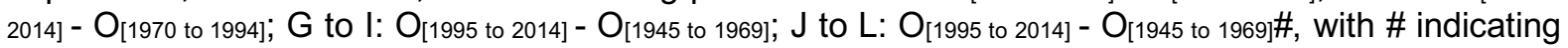
the exclusive plotting of $\mathrm{H}$ bins for which 25 year climatological values are available for each of the three 25 year periods, and that display monotonic trends (increasing or decreasing) from 1945 to 2014 . The zero contour line is shown. 


\section{REFERENCES}

Atkinson, L.P., Lee, T.N., 1983. Climatology of the Southeastern United States Continental Shelf Waters. J. Geophys. Res. 88 (C8), 4705-4718.

Augustyn, J.A., Cockcroft, A.C., Kerwath, S., Lamberth, S.J., Githaiga-Mwicigi, J., Pitcher, G.C., Roberts, M., van der Lingen, C.D., Auerswald, L., 2017. Climate change impacts on fisheries and aquaculture: a global analysis. In: Phillips, B.F., Perez-Ramírez, M. (Eds.), The Impacts of Climate Change on Fisheries and Aquaculture: a Global Analysis. John Wiley and Sons Ltd., Hoboken, USA, pp. 479-522.

Bakun, A., Black, B.A., Bograd, S.J., García-Reyes, M., Miller, A.J., Rykaczewski, R.R., Sydeman, W.J., 2015. Anticipated Effects of Climate Change on Coastal Upwelling Ecosystems. Curr. Clim. Change Rep. 1, 85-93. https://doi.org/10.1007/s40641-015-0008-4.

Beal, L.M., Elipot, S., 2015. Broadening not strengthening of the Agulhas Current since the early 1990s. Nature 540 (7634), 570-573.

Bindoff, N.L., Cheung, W.W.L., Kairo, J.G., Aristegui, J., Guinder, V.A., Hallberg, R., et al., 2019. Changing Ocean, Marine Ecosystems, and Dependent Communities. In: IPCC Special Report on the Ocean and Cryosphere in a Changing Climate. H.-O. Pörtner, Roberts, D.C., Masson-Delmotte, V., Zhai, P., Tignor, M., Poloczanska, E., et al. (Eds.), 2019.

Bisagni, J.J., 2016. Salinity variability along the eastern continental shelf of Canada and the United States, 1973-2013. Cont. Shelf Res. 126, 89-109.

Blamey, L.K., Shannon, L.J., Bolton, J.L., Crawford, R.J.M., Dufois, F., Evers-King, H., Griffiths, C.L., et al., 2015. Ecosystem change in the southern Benguela and the underlying processes. J. Mar. Syst. 144, 9-29. https://doi.org/10.1016/j.jmarsys.2014.11.006.

Blanton, B.O., Aretxabaleta, A., Werner, F.E., Seim, H.E., 2003. Monthly climatology of the continental shelf waters of the South Atlantic Bight. J. Geophys. Res. 108 (C8), 3264. doi:10.1029/2002JC001609.

Boyer, T., Levitus, S., Garcia, H., Locarnini, R.A., Stephens, C., Antonov, J., 2005. Objective analyses of annual, seasonal, and monthly temperature and salinity for the world ocean on a $0.25^{\circ}$ grid. Int. J. Climatol. 25, 931-945.

Boyer, T.P., Baranova, O.K., Coleman, C., Garcia, H.E., Grodsky, A., Locarnini, R.A., Mishonov, A.V., Paver, C.R., Reagan, J.R., Seidov, D., Smolyar, I.V.,Weathers, K.W., Zweng, M.M., (2018). World Ocean Database 2018. A.V. Mishonov (Technical Ed.), NOAA Atlas NESDIS 87, 207 pp.

Bremner, J.M., 1981. Shelf morphology and surficial sediment off Central and Northern South West Africa (Namibia). Geo-Mar. Lett. 1(2), 91-96.

Briggs, J.C., Bowen, B.W. (2012). A realignment of marine biogeographic provinces with particular reference to fish distributions. J. Biogeogr. 39, 12-30.

Cavole, L.M., Demko, A.M., Diner, R.E., Giddings, A., Koester, I., Pagniello, C.M.L.S., et al., 2016. Biological impacts of the 2013-2015 warm-water anomaly in the Northeast Pacific: winners, losers, and the future. Oceanography $29,273-285$.

Chapman, P., Shannon, L.V., 1987. Seasonality in the oxygen minimum layers at the extremities of the Benguela system. S. Afr. J. Mar. Sci. 5 (1), 85-94. doi:10.2989/025776187784522162.

Cheung, W.W.L., Watson, R., Pauly, D., 2013. Signature of ocean warming in global fisheries catch. Nature 497, 365-368. 
Chiocci, F.L., Chivas, A.R. (Eds), 2014. Continental Shelves of the World: Their Evolution During the Last Glacio-Eustatic Cycle. Geological Society, London, Memoirs 41, 1-5.

http://dx.doi.org/10.1144/M41.1.

Cockcroft, A.C., van Zyl, D., Hutchings, L., 2008. Large-scale changes in the spatial distribution of South African West Coast rock lobsters: an overview. Afr. J. Mar. Sci. 30 (1), 149-159. https://doi.org/10.2989/AJMS.2008.30.1.15.465.

Coetzee, J.C., van der Lingen, C.D., Hutchings, L., Fairweather, T.P., 2008. Has the fishery contributed to a major shift in the distribution of South African sardine?. ICES J. Mar. Sci. 65, 16761688. https://doi.org/10.1093/icesjms/fsn184.

Costanza, R., D'Arge, R., de Groot, R., et al., 1997. The value of the world's ecosystem services and natural capital. Nature 387, 253-260.

de Villiers, S., Thiart, C., 2007. The nutrient status of South African rivers: concentrations, trends and fluxes from the 1970's to 2005 . S. Afr. J. Sci. 103, 343-349.

Dias, C.A., 1983. Note on the evidence of a permanent southward flow of the upper oceanic tropospheric waters off Angola at $12^{\circ}$ S. Collect. Sci. Pap. ICSEAF 10, 99-102.

Dingle, R.V., Goodlad, S.W., Martin, A.K., 1978. Bathymetry and stratigraphy of the northern Natal valley (SW Indian Ocean): a preliminary account. Mar. Geol. 28, 89-106.

Duncombe Rae, C.M., 1991. Agulhas retroflection rings in the South Atlantic Ocean: an overview. S.Afr. J. Mar. Sci. 11 (1), 327-344.

Ekau, W., Verheye, H.M., 2005. Influence of oceanographic fronts and low oxygen on the distribution of ichthyoplankton in the Benguela and southern Angola currents. Afr. J. Mar. Sci. 27, 629-639.

Fairweather, T.P., van der Lingen, C.D., Booth, A.J., Drapeau, L., van der Westhuizen, J.J., 2006. Indicators of sustainable fishing for South African sardine (Sardinops sagax) and anchovy (Engraulis encrasicolus). Afr. J. Mar. Sci. 28, 661-680.

Gammelsrød, T., Bartholomae, C.H., Boyer, D.C., Filipe, V.L.L., O'Toole, M.J., 1998. Intrusion of warm surface water along the Angolan-Namibian coast in February-March 1995: the 1995 Benguela Nino: In: Pillar, S.C., Moloney, C.L., Payne, A.L.L., Shillington, F.A. (Eds.), Benguela Dynamics: Impacts of Variability on Shelf-Sea Environments and their living resources, S. Afr. J. Mar. Sci. 19, 4156.

Gordon, A.L., Bosley, K.T., 1991. Cyclonic gyre in the tropical South Atlantic. Deep-Sea Res. 38, S323-343.

Hamukuaya, H., O'Toole, M.J., Woodhead, P.M.J., 1998. Observation of severe hypoxia and offshore displacement of Cape Hake over the Namibian shelf in 1994. In: Pillar, S.C., Moloney, C.L., Payne, A.I.L., Shillington, F.A. (Eds.), Benguela Dynamics: Impacts of variability on Shelf-Sea Environments and their living resources. S.Afr.J.Mar.Sci. 19, 57-59.

Hobday, A.J., Pecl, G.T., 2014. Identification of global marine hotspots: sentinels for change and vanguards for adaptation action. Rev. Fish Biol. Fish. 24 (2), 415-425.

https://doi.org/10.1007/s11160-013-9326-6.

Hutchings, L., van der Linden, C.D., Shannon, L.J., Crawford, R.J.M., et al., 2009. The Benguela Current: an ecosystem of four components. Prog. Oceanogr. 83, 15-32.

Jarre, A., Hutchings, L., Kirkman, S.P., Kreiner, A., Tchipalanga, C.M.P., Kainge, P., Uanivi, U., van der Plas, A.K., Blamey, K.L., Coetzee, C.J., Lamont, T., Samaai, T., Verheye, M.H., Yemane, G.D., Axelsen, E.B., Ostrowski, M., Stenevik, K.E., Loeng, H., 2015a. Synthesis: climate effects on biodiversity, abundance and distribution of marine organisms in the Benguela. Fish. Oceanogr. 24 (Suppl. 1), 122-149. https://doi.org/10.1111/fog.12086.

Jarre, A., Hutchings, L., Crichton, M., Wieland, K., Lamont, T., Blamey, L.K., Illert, C., Hill, E., van den Berg, M., 2015b. Oxygen-depleted bottom waters along the west coast of South Africa, 1950-2011. Fish. Oceanogr. 24 (Suppl. 1), 56-73. 
Jones, T., Parrish, J.K., Peterson, W.T., Bjorkstedt, E.P., Bond, N.A., Ballance, L.T., et al., 2018. Massive mortality of a planktivorous seabird in response to a marine heatwave. Geophys. Res. Lett. 45, 3193-3202. doi: 10.1002/2017gl076164.

Kainge, P., Kirkman, S.P., Estevão, V., Van der Lingen, C.D., Uanivi, U., Kathena, J.N., Van der Plas, A., et al., 2020. Fisheries yields, climate change, and ecosystem-based management of the Benguela Current Large Marine Ecosystem." Env. Development, 100567. doi:10.1016/j.envdev.2020.100567.

Kainge, P., Van der Plas, A.K., Barthlolomae, C.H., Wieland, K., 2017. Effects of environmental variables on survey catch rates and distribution by size of shallow- and deep-water Cape hakes, Merluccius capensis and Merluccius paradoxus off Namibia. Fish. Oceanogr. 26, 680-692.

Kerr, R.A., 2000. A North Atlantic climate pacemaker for the centuries. Science 288 (5473), 19841986.

Knudsen, M.F., Seidenkrantz, M-S., Jacobsen, B.H., Kuijpers, A., 2011. Tracking the Atlantic Multidecadal Oscillation through the last 8,000 years. Nat. Comm. 2, 178. doi:10.1038/ncomms1186.

Lamont, T., Garcia-Reyes, M., Bograd, S.J., van der Lingen, C.D., Syderman, W.J., 2018. Upwelling indices for comparative ecosystem studies: variability in the Benguela Upwelling Ecosystem. J. Mar. Syst. 188, 3-16. doi:10.1016/j.jmarsys.2017.05.007.

Leduc, G., Herbert, C.T., Blanz, T., Martinez, P., Schneider, R., 2010. Contrasting evolution of sea surface temperature in the Benguela upwelling system under natural and anthropogenic climate forcings. Geophys. Res. Lett. 37, L20705. doi:10.1029/2010GL044353.

Levitus, S., 1982. Climatological Atlas of the World Ocean. NOAA Professional Paper 13. US. Government Printing Office, Washington DC.

Levitus, S., Boyer, T.P., 1994. World Ocean Atlas 1994: Volume 4: Temperature. NOAA Atlas NESDIS 4. US Government Printing Office, Washington DC.

Lutjeharms, J.R.E., 2006. The coastal oceans of south-eastern Africa. In: The global coastal ocean: The Sea - Ideas and observations on the progress in the study of the seas, Vol 14 (B), A.R. Robinson and K.H. Brink (Eds.), pp. 783-834, Cambridge, Mass., Harvard University Press.

Lutjeharms, J.R.E., Biastoch, A., Van der Werf, P.M., Ridderinkhof, H., de Ruitjer, W.P.M., 2012. On the discontinuous nature of the Mozambique Current. S. Afr. J. Sci. 108 (1/2), Art. \#428. http://dx.doi.org/10.4102.sajs.v108i1/2.428.

Lutjeharms, J.R.E., Cooper, J., 1996. Interbasin leakage through Agulhas Current filaments. Deep Sea Res. 43, 213-238.

Lutjeharms, J.R.E., Meyer, A.A., Ansorge, I.J., Eagle, G.A., Orren, M.J., 1996. The nutrient characteristics of the Agulhas Bank. S. Afr. J. Mar. Sci. 17, 253-274.

Lutjeharms, J.R.E., van Ballegooyen, R.C., 1988. The retroflection of the Agulhas Current. J. Phys. Oceanogr. 18, 1570-1583.

Malan, N., Durgadoo, J.V., Biastoch, A., Reason, C., Hermes, J., 2019. Multidecadal wind variability drives temperature shifts on the Agulhas Bank. J. Geophys. Res. (Oceans) 124, 3021-3035.

Mbatha, F.L., Yemane, D., Ostrowski, M., Moloney, C.L., Lipinski, M.R., 2019. Oxygen and temperature influence the distribution of deepwater Cape hake Merluccius paradoxus in the southern Benguela: a GAM analysis of a 10-year time-series. Afr. J. Mar. Sci. 41(4), 413-427.

Mazeika, P.A., 1967. Thermal domes in the eastern tropical Atlantic Ocean. Limnol. Oceanogr. 12, 537-539.

Mercier, H., Arhan, M., Lutjeharms, J.R.E., 2003. Upper-layer circulation in the eastern Equatorial and South Atlantic Oceans in January-March 1995. Deep-Sea Res. I, 50, 863-887. 
Mills, K.E., Pershing, A.J., Brown, C.J., Chen, Y., Chiang, F.-S., Holland, D.S., et al., 2012. Lessons from the 2012 ocean heat wave in the Northwest Atlantic. Oceanography 26, 60-64.

Mohrholz, V., Bartholomaeb, C.H., Plas van der, A.K., Lass, H.U., 2008. The seasonal variability of the northern Benguela undercurrent and its relation to the oxygen budget on the shelf. Cont. Shelf Res. 28, 424-441.

Morley, J.W., Selden, R.L., Latour, R.J., Frölicher, T.L., Seagraves, R.J.,Pinsky, M.L., 2018. Projecting shifts in thermal habitat for 686 species on the North American continental shelf. PLoS ONE 13(5): e196127. https://doi.org/10.1371/journal.pone.0196127.

Olivar, M.P., Shelton, P.A., 1993. Larval fish assemblages of the Benguela Current. Bull. Mar. Sci. $53,450-474$.

Oliver, E.C.J., Donat, M.G., Burrows, M.T., Moore, P.J., Smale, D.A., Alexander, L.V., et al., 2018. Longer and more frequent marine heatwaves over the past century. Nat. Commun. 9, 1324. doi: 10.1038/s41467-018-03732-9.

Oliver, E.C.J., Burrows, M.T., Donat, M.G., Gupta, A.S., Alexander, L.V., Perkins-Kirkpatrick, S.E., et al., 2019. Projected marine heatwaves in the 21 st century and the potential for ecological impact. Front. Mar. Sci. 6, 734. doi: 10.3389/fmars.2019.00734.

Orme, A.R. 1982. Africa, coastal morphology. In: Beaches and Coastal Geology. Encyclopedia of Earth Science. Springer, Boston, MA.

Pauly, D., 1998. Large marine ecosystems: analysis and management. S. Afr. J. mar. Sci. 19, 487499.

Pinsky, M.L., Selden, R.L., Kitchel, Z.J., 2019. Ranges: scaling from organisms to communities. Ann. Rev. Mar. Sci. 12, 153-179.

Potts, W.M., Henriques, R., Santos, C.V., Munnik, K., Ansorge, I., DuFois, F., Booth, A.J., Kirchner, C., Sauer, W.H.H., Shaw, P.W., 2014. Ocean warming, a rapid distributional shift, and the hybridization of a coastal fish species. Global Change Biol. 20 (9), 2765-2777. https://doi.org/10.1111/gcb.12612.

Potts, W.M., Götz, A., James, N., 2015. Review of the projected impacts of climate change on coastal fishes in southern Africa. Rev. Fish Biol. Fisheries, doi: 10.1007/s11160-015-9399-5.

Probyn, T.A., Mitchell-Innes, B.A., Brown, P.C., Hutchings, L., Carter, R.A., 1994. A review of primary production and related processes on the Agulhas Bank. S. Afr. J. Sci. 90, 166-173.

Richaud, B., Kwon, Y-O., Joyce, T.M., Fratantoni, P.S., Lentz, S.J., 2016. Surface and bottom temperature and salinity climatology along the continental shelf off the Canadian and U.S. East Coasts. Cont. Shelf Res. 124, 165-181.

Ridgway K.R., Dunn, J.R., Wilkin, J.L., 2002. Ocean interpolation by four-dimensional least squares Application to the waters around Australasia. J. Atmos. Ocean. Tech. 19 (9) 1357-1375.

Rouault, M., Pohl,B., Penven, P., 2010. Coastal oceanic climate change and variability from 1982 to 2009 around South Africa. Afr. J. Mar. Sci. 32 (2), 237-246.

Rouault, M., Illig, S., Lubbecke, J., Koungue, R.A.I., 2017. Origin, development and demise of the 2010-11 Benguela nino. J. Mar. Syst. 188, 39-48. doi: 10.1016/j.marsys.2017.07.007.

Roy, C., van der Lingen, C.D., Coetzee, J.C., Lutjeharms, J.R.E., 2007. Abrupt environmental shift associated with changes in the distribution of Cape anchovy Engraulis encrasicolus spawners in the southern Benguela. Afr. J. Mar. Sci. 29 (3), 309-319. https://doi.org/10.2989/AJMS.2007.29.3.1.331

Russo, A., Bergamasco, A., Carniel, S., Grieco, L., Sclavo, M., Spezie, G., 2011. Climatology and decadal variability of the Ross Sea shelf waters. Adv. Oceanogr. Limnol. 2(1), 55-77. 
Santos, F., Gomez-Gesteira, M., deCastro, M., Alvarez, I., 2012. Differences in coastal and oceanic SST trends due to the strengthening of coastal upwelling along the Benguela current system. Cont. Shelf Res. 34, 79-86.

Schlitzer, R., 2018. Ocean Data View, https://odv.awi.de.

Schumann, E.H., 1998. The Coastal Ocean off Southeast Africa, including Madagascar. Coastal segment (15,W). Chapter 19 in: The Sea, Volume 11, Robinson, A.R., and Brink, K.H. (Eds.), John Wiley \& Sons, Inc., pp. 557-581.

Scrutton, R.A. (Ed.), 1982. Dynamics of Passive Margins. Geodynamics Series, Vol 6. AGU.

Shannon, L.V., Boyd, A.J., Brundrit, G.B., Taunton-Clarke, J., 1986. On the existence of an El Ninotype phenomenon in the Benguela system. J. Mar. Res. 44(3), 495-520.

Shannon, L.V., 1995. The physical environment. In: Payne, A.I.L., Crawford, R.J.M. (Eds). Oceans of life off southern Africa, 2nd edn. Vlaeberg, Cape Town, pp. 136-147.

Sherman, K., 1993. Large marine ecosystems as global units for marine resources management - an ecological perspective. In Large Marine Ecosystems: Stress, Mitigation, and Sustainability, Sherman, K., Alexander, L.M., Gold, B.D. (Eds). Washington, D.C., AAAS Press, 3-14.

Smale, D.A., Wernberg, T., Oliver, E.C.J., Thomsen, M., Harvey, B.P., Straub, S.C., et al., 2019. Marine heatwaves threaten global biodiversity and the provision of ecosystem services. Nat. Clim. Chang. 9, 306-312. doi: 10.1038/s41558-019-0412-1.

Sonwa, D.J., Farikou, M.O., Martial, G., Félix, F.L., 2020. Living under a fluctuating climate and a drying Congo Basin. Sustainability, 12, 2935. doi:10.3390/su1207936.

Spalding, M.D., Agostini, V., Rice, J., Grant, S.M., 2012. Pelagic provinces of the world: A biogeographic classification of the world's surface pelagic waters. Ocean Coast. Man. 60, 19-30.

Stramma, L., Schott, F., 1999. The mean flow of the tropical Atlantic Ocean. Deep-Sea Res. II 46, 279-303.

Sunday, J.M., Bates, A.E., Duty, N.K., 2012. Thermal tolerance and the global redistribution of animals. Nat. Clim. Change 2, 686-690.

Swallow, J.C., Schott, F., Fieux, M., 1991. Structure and transport of the East African Coastal Current. J. Geophys. Res. Atmosph. 962 (C12), 22245-22257.

Tchipalanga, P., Dengler, M., Brandt, P.D.T., Kopte, R., Macuéria, M., Coelho, P., Ostrowski, M., Keenlyside, N.S., 2018. Eastern boundary circulation and hydrography off Angola - building Angolan oceanographic capacities. Bull. Am. Meteorol. Soc. 99(8), 1589-1605. doi:10.1175.BAMS-D-170197.1.

UNEP (United Nations Environment Programme), 2006. Marine and Coastal Ecosystems and Human Well-being: A Synthesis Report Based on the Findings of the Millennium Ecosystem Assessment. Nairobi: UNEP.

Van der Lingen, C.D., Hutchings, L., Pitcher, G.C. Lamont, T., 2016. Climate change, dinoflagellate blooms and sardine in the southern Benguela current large marine ecosystem. Environ. Develop. 17, 230-243.

van der Lingen, C.D., Hampton, I., 2018. Climate change impacts, vulnerabilities and adaptations: Southeast Atlantic and Southwest Indian Ocean marine fisheries. In: Barange, M., Bahri, T., Beveridge, M.C.M., Cochrane, K.L., Funge-Smith, S., Poulain, F. (Eds.), Impacts of Climate Change on Fisheries and Aquaculture: Synthesis of Current Knowledge, Adaptation and Mitigation Options. FAO Fisheries and Aquaculture Technical Paper No. 627, p. 628. Rome, FAO

Wernberg, T., Bennett, S., Babcock, R.C., de Bettignies, T., Cure, K., Depczynski, M., et al., 2016. Climate-driven regime shift of a temperate marine ecosystem. Science 353, 169-172. doi: 10.1126/science.aad8745. 
1

Whitfield, A.K. , 2005. Preliminary documentation and assessment of fish diversity in sub-Saharan African estuaries. Afr. J. Mar. Sci. 27, 307-324.

Woodhead, P.M., Hamukuaya, H., O'Toole, M.J., Strømme, T., Saetersdal, G., Reiss, M., 1997. Catastrophic loss of two billion Cape hake recruits during widespread anoxia in the Benguela Current of Namibia. In: Proceedings of ICES International Symposium on recruitment of exploited marine populations: Physical-Biological Interactions, pp. 105-106. September 22-24, 1997, Baltimore, MD.

Vizy, E.K., Cook, K.H., Sun, X., 2018. Decadal change of the south Atlantic Ocean Angola-Benguela frontal zone since 1980. Clim. Dynam. https://doi.org/10.1007/ s00382-018-4077-7).

Yemane, D., Kirkman, S.P., Kathena, J., N'siangango, S.E., Axelsen, B.E., Samaai, T., 2014.

Assessing changes in the distribution and range size of demersal fish populations in the Benguela Current Large Marine Ecosystem. Rev. Fish Biol. Fish. 24 (2), 463-483. https://doi.org/10.1007/s11160-014-9357-7. 


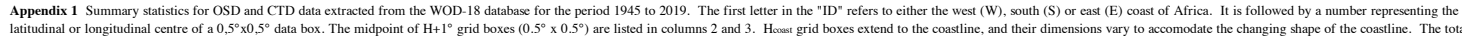

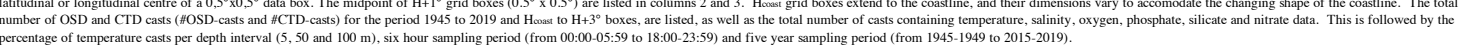

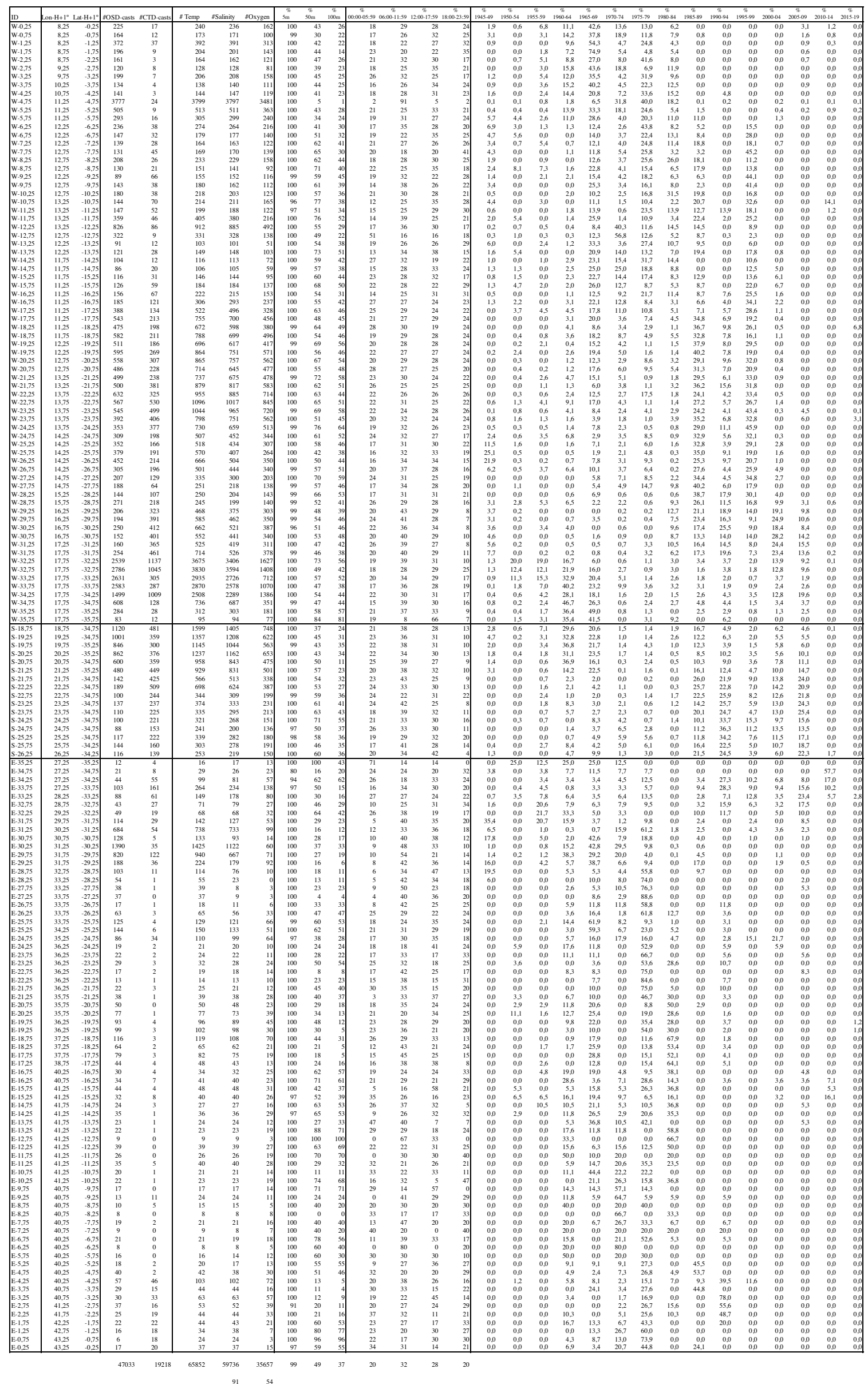


Appendix 2 WOD-18 data points excluded from the

climatology, for each of the variables studied. The unique WOD Station ID can be used to find ancillary data for the

particular station, at ncei.noaa.gov.

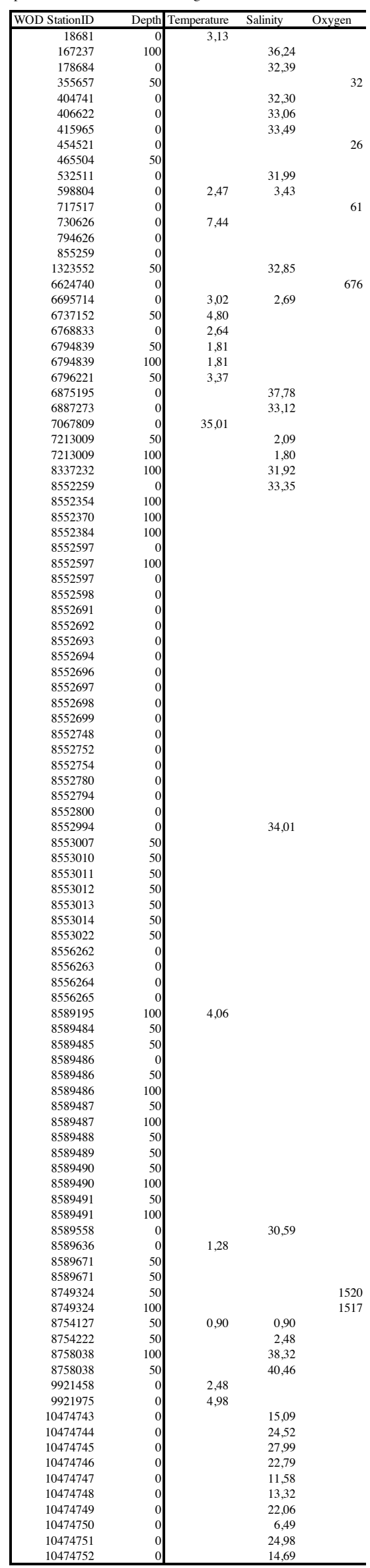




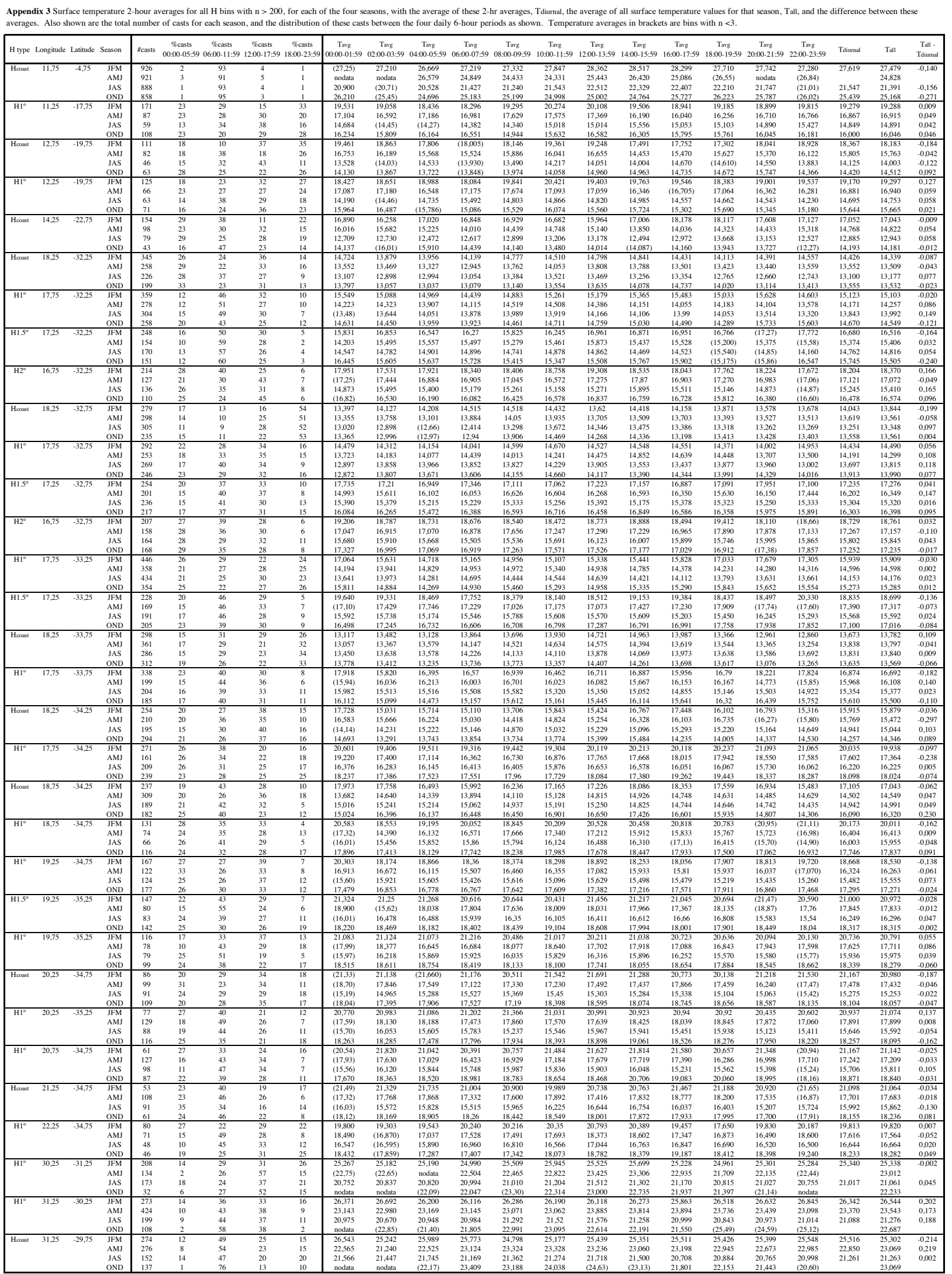


Appendix 4 The standard deviation associated with the average of all available temperature data, and the standard deviation associated with the average of the the four seasonal climatological averages, at depths of 5,50 and $100 \mathrm{~m}$.

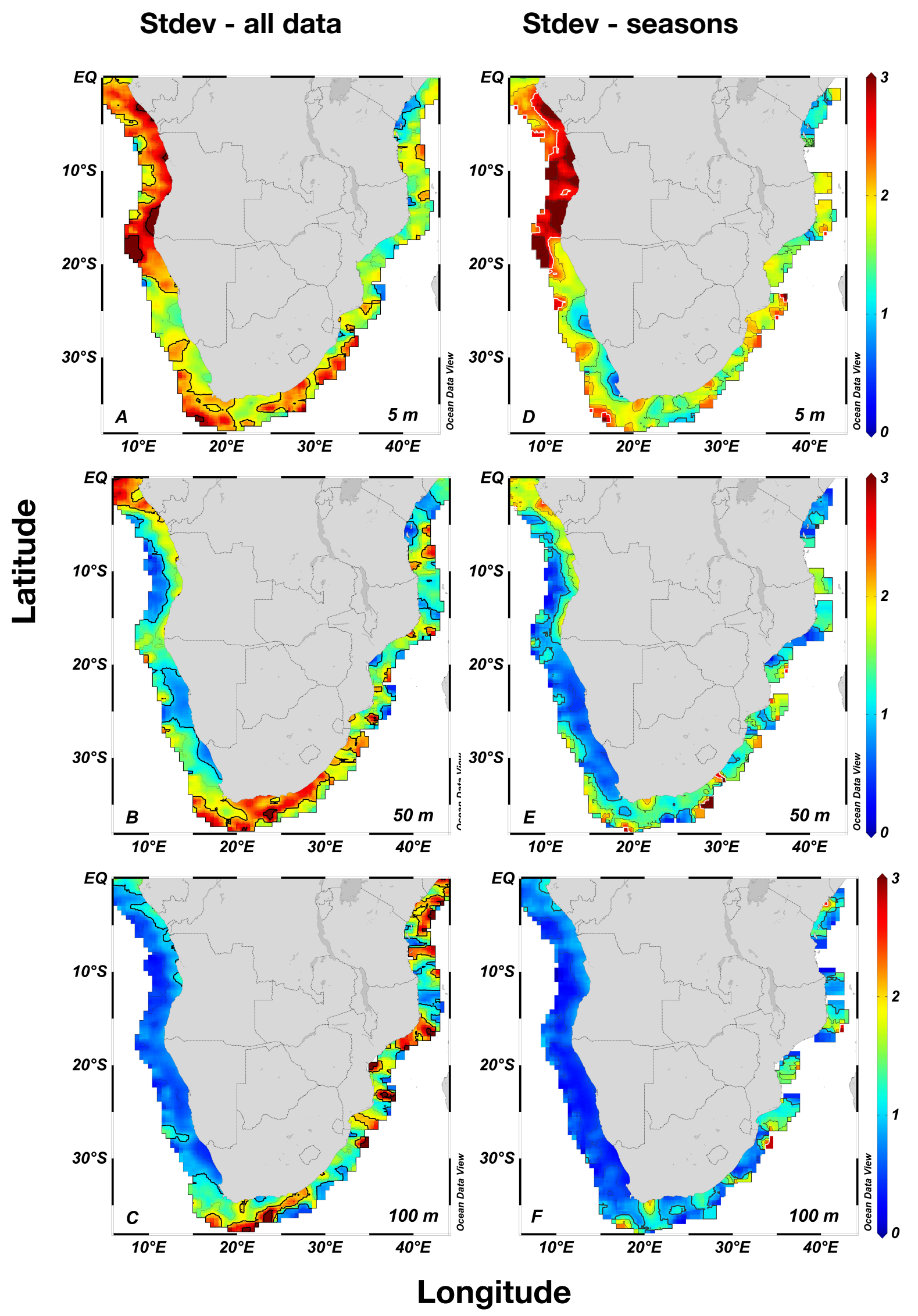

